\title{
Sensory Evaluation and Quality Indicators of Nutritionally Enhanced Egg Product with Omega-3 Rich Oils
}

\author{
Helenia Dawn Sedoski \\ West Virginia University
}

Follow this and additional works at: https://researchrepository.wvu.edu/etd

\section{Recommended Citation}

Sedoski, Helenia Dawn, "Sensory Evaluation and Quality Indicators of Nutritionally Enhanced Egg Product with Omega-3 Rich Oils" (2011). Graduate Theses, Dissertations, and Problem Reports. 4785.

https://researchrepository.wvu.edu/etd/4785

This Thesis is protected by copyright and/or related rights. It has been brought to you by the The Research Repository @ WVU with permission from the rights-holder(s). You are free to use this Thesis in any way that is permitted by the copyright and related rights legislation that applies to your use. For other uses you must obtain permission from the rights-holder(s) directly, unless additional rights are indicated by a Creative Commons license in the record and/ or on the work itself. This Thesis has been accepted for inclusion in WVU Graduate Theses, Dissertations, and Problem Reports collection by an authorized administrator of The Research Repository @ WVU. For more information, please contact researchrepository@mail.wvu.edu. 
Sensory Evaluation and Quality Indicators of Nutritionally Enhanced Egg Product with Omega-3 Rich Oils.

Helenia Dawn Sedoski

Thesis submitted to the

Davis College of Agriculture, Natural Resources and Design

At West Virginia University

In partial fulfillment of the requirements

for the degree of

Master of Science

in

Animal and Nutritional Sciences

Kristen Matak, Ph.D., Chair
Jacek Jaczynski, Ph.D.
Susan Partington, Ph.D., RD

Division of Animal and Nutritional Sciences

Morgantown, West Virginia

2011 


\section{Abstract \\ Sensory Evaluation and Quality Indicators of Nutritionally Enhanced Egg Product with Omega-3 Rich Oils. \\ Helenia Dawn Sedoski}

Heart disease is a leading cause of death in the United States. Omega-3 (n-3) fatty acids (FA) positively affect heart health while high levels of cholesterol are an indication of poor heart health. Nutritionally-enhanced low-cholesterol egg sticks fortified with n-3 FA were developed; quality indicators were measured and sensory evaluations were conducted. Store-bought eggs were separated and egg whites were mixed with oil, spray dried egg whites, annatto (color) and salt. The oil sources included: algae, menhaden, flaxseed, and canola oils. Experimental egg batters and mixed whole egg (control) were cooked in the shape of a cheese stick, vacuum packed, and stored at 4C. Quality indicators (color $\left(\mathrm{L}^{*}, \mathrm{a}^{*}, \mathrm{~b}^{*}\right)$, texture, $\mathrm{pH}$ and lipid oxidation) of egg sticks were measured over a storage period of 14-d. There were no changes in color over time $(P>0.05)$; however, whole egg was significantly less red and yellow compared to experimental eggs $(P<0.05)$. Significant differences in texture properties were observed $(\mathrm{P}<0.05)$ but these were independent of time $(\mathrm{P}>0.05)$. A difference in $\mathrm{pH}$ between egg types was seen $(\mathrm{P}<0.05)$; however, the $\mathrm{pH}$ for each egg type did not change over time $(P>0.05)$. No trend in lipid oxidation was seen over storage time $(P>0.05)$. Egg sticks were evaluated by a consumer panel of 56 participants for color, odor, flavor, texture between fingers, mouth feel and overall liking with a 9-point scale (1=dislike extremely; $9=$ like extremely). Panelists also ranked samples from most to least liked. The texture between fingers of the whole egg was significantly more liked than the experimental eggs containing DHAS and canola oils $(\mathrm{P}<0.05)$. Odor scores were significantly greater $(P<0.05)$ in whole egg compared to the experimental egg containing flaxseed oil. No 
significant preference was observed in mouthfeel or flavor. All samples were well-liked, with a combined average score of 5.9. Ranking results support this conclusion with no significant differences in preference $(P>0.05)$. The results indicate that the experimental eggs are accepted by consumers on the same level as mixed whole eggs and may have potential as a marketable product.

Key words: Omega-3, Egg, TBARS, texture profile analysis, functional food, egg composition, sensory evaluation 


\section{Acknowledgements}

I would first like to thank Sarah Beamer for her willingness to share her knowledge of laboratory tests and her above and beyond availability. I would like to thank my committee members, Kristen Matak, PhD., Jacek Jaczynski, PhD. And Susan Partington, PhD., RD for their assistance. Thank you to thank Kaitlin Maditz and Brittney Pietrowski for all their help and with lab analysis and helping complete the sensory analysis.

I would also like to thank Kristen Matak, PhD., for the countless revision suggestions, having such an open door and always responding to questions. I appreciate her trust and allowing me to complete this project. Thank you to Jacek Jaczynski, PhD., Brett Kenney, PhD., and Tammy Webster for the use of their labs and equipment. Thanks to Susan Slider for the experimental advice.

I would like to thank my family and friends for their encouragement. Last but not least, I want to thank my husband, John, for not only never complaining about the long hours I spent away from home but always encouraging me. 


\section{Table of Contents}

\section{Contents}

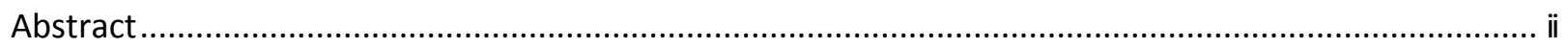

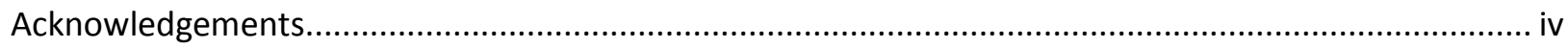

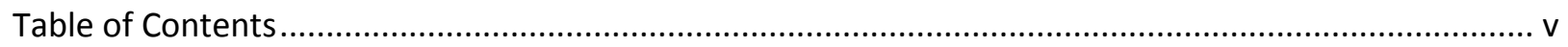

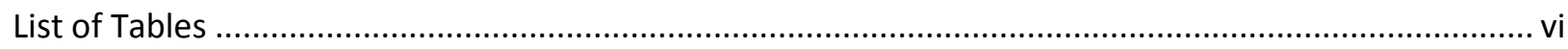

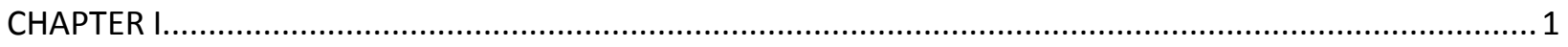

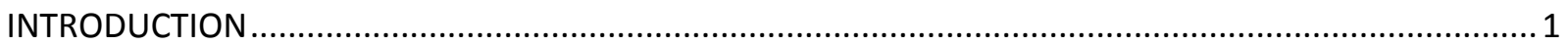

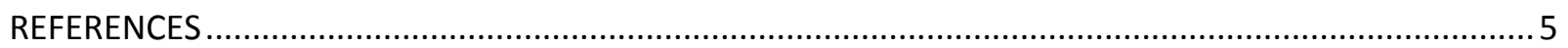

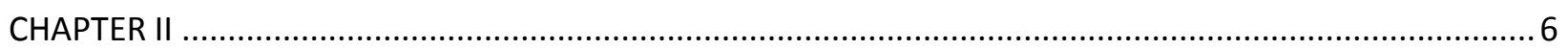

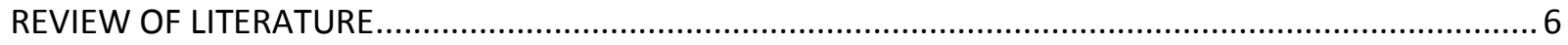

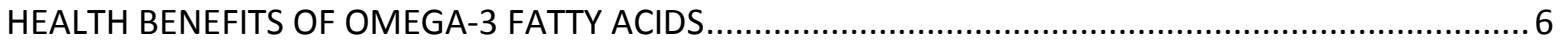

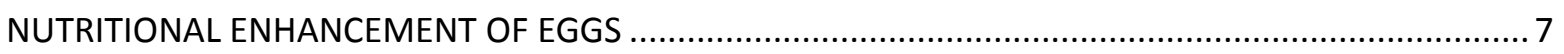

LIPID OXIDATION

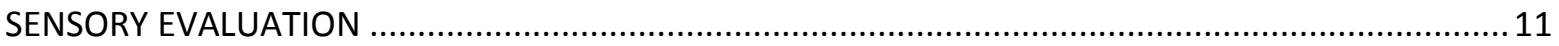

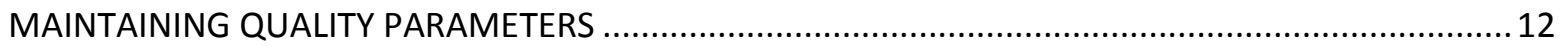

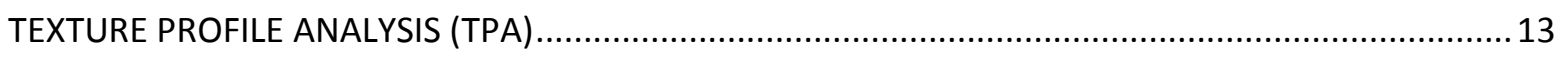

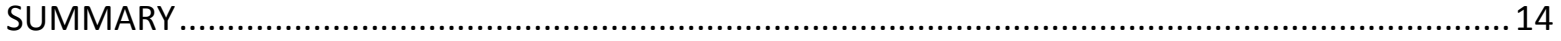

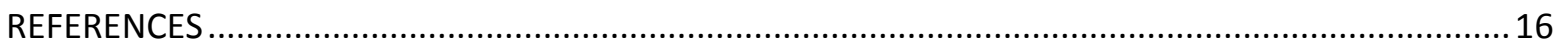

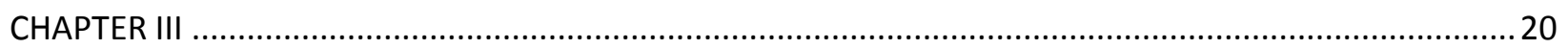

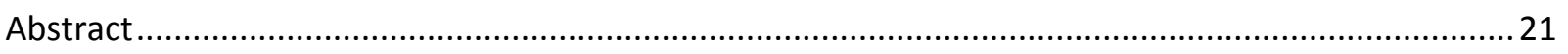

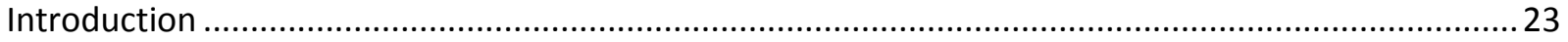

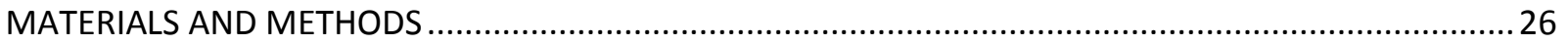

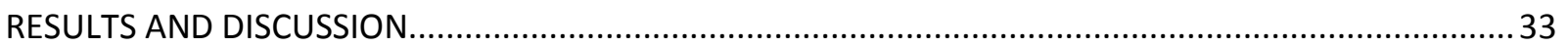

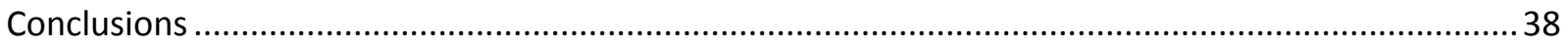

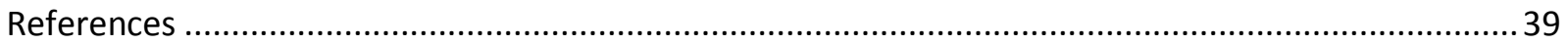

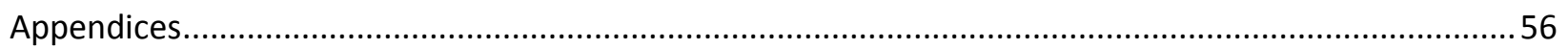

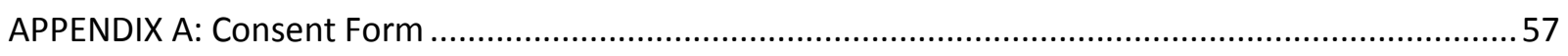

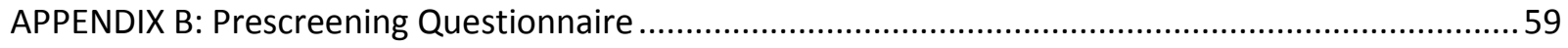

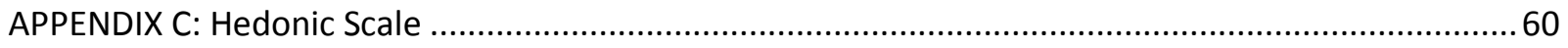

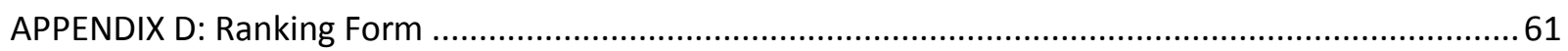




\title{
List of Tables
}

\author{
Chapter III
}

Table 1. $\mathrm{pH}$ of cooked whole egg and experimental eggs with addition of canola, flaxseed, menhanden, DHAS (algae) and a blend of DHAS, flaxseed and krill oils over a two-week storage period with no significant differences in each sample over storage

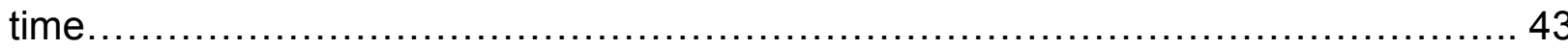

Table 2. Lightness color values $(L)$ of cooked whole egg and experimental eggs with addition of canola, flaxseed, menhanden, DHAS (algae) and a blend of DHAS, flaxseed and krill oils over a two-week storage period with no differences in each sample over time ............................................................................................ 44

Table 3. $a^{*}$ color values (positive value $=$ reddish hue, negative value $=$ greenish hue) of cooked whole egg and experimental eggs with addition of canola, flaxseed, menhanden, DHAS (algae) and a blend of DHAS, flaxseed and krill oils over a twoweek storage period with no differences in each sample over time.

Table 4. $b^{*}$ color values (positive value = yellowish, negative value = bluish hue) of cooked whole egg and experimental eggs with addition of canola, flaxseed, menhanden, DHAS (algae) and a blend of DHAS, flaxseed and krill oils over a twoweek storage period with no differences in each sample over time.

Table 5. Syneresis expressed as percent weight loss of cooked whole egg and experimental eggs with addition of canola, flaxseed, menhanden, DHAS (algae) and a blend of DHAS, flaxseed and krill oils over a two-week storage period.

Table 6. $\mathrm{mg} \mathrm{MDA} / \mathrm{kg}$ sample in cooked whole egg and experimental eggs with addition of canola, flaxseed, menhanden, DHAS (algae) and a blend of DHAS, flaxseed and krill oils over a two-week storage period.

Table 7. Springiness of cooked whole egg and experimental eggs with addition of canola, flaxseed, menhanden, DHAS (algae) and a blend of DHAS, flaxseed and krill oils over a two-week storage period.

Table 8. Gumminess of cooked whole egg and experimental eggs with addition of canola, flaxseed, menhanden, DHAS (algae) and a blend of DHAS, flaxseed and krill oils over a two-week storage period with no significant differences in each sample over storage time 
Table 9. Cohesiveness of cooked whole egg and experimental eggs with addition of canola, flaxseed, menhanden, DHAS (algae) and a blend of DHAS, flaxseed and krill oils over a two-week storage period.

Table 10. Chewiness of cooked whole egg and experimental eggs with addition of canola, flaxseed, menhanden, DHAS (algae) and a blend of DHAS, flaxseed and krill oils over a two-week storage period with no significant differences in each sample over storage time

Table 11. Resilience of cooked whole egg and experimental eggs with addition of canola, flaxseed, menhanden, DHAS (algae) and a blend of DHAS, flaxseed and krill oils over a two-week storage period with no significant differences in each sample over storage time.

Table 12. Hardness of cooked whole egg and experimental eggs with addition of canola, flaxseed, menhanden, DHAS (algae) and a blend of DHAS, flaxseed and krill oils over a two-week storage period with no significant differences in each sample over storage time.

Table 13. Sensory attribute evaluation and ranking of cooked whole egg and experimental eggs with addition of canola, flaxseed, DHAS (algae). 


\section{CHAPTER I}

\section{INTRODUCTION}

Most fatty acids (FA) can be synthesized by processes called desaturation and elongation (Hanebutt, et al., 2008). Humans lack a desaturase enzyme that can create a double bond on the third carbon from the omega terminal meaning that omega-3 $(n-3)$ FAs must be consumed in the diet in order to be present in the body. Alpha-linolenic acid (ALA, 18:3 n-3) is an essential FA found in plants. ALA may be converted to docosahexaenoic acid (DHA, 22:6 n-3) and eicosapentaenoic acid (EPA, 20:5 n-3); however, this conversion is relatively low in humans (Hanebutt, et al., 2008). Therefore, it is best to consume these metabolites in the diet.

There are many health benefits with n-3 FA consumption, particularly EPA and DHA. The most extensively researched benefit is the reduced risk of cardiovascular disease (CVD). This may occur secondary to the reduction in blood pressure (BP), arrhythmias and the rate of atherosclerotic plaque buildup and platelet aggregation which decreases the number of thrombi. Blood lipid profile can also be improved. EPA and DHA have been shown to reduce low density lipoproteins (LDL: known as bad cholesterol). Omega-3 FAs produce n-3 series eicosanoids. These eicosanoids include prostaglandins, leukotrienes and thromboxins. N-3 series eicosanoids are weaker than n-2 (pro-inflammatory) series eicosanoids produced by arachidonic acid (AA), an essential n-6 FA. By the process of competitive inhibition the n-3 series reduces the production of the $\mathrm{n}-2$ series. This leads to reduced inflammation of the blood vessels, making it easier for blood to flow. 
The recommended intake for n-3 FAs is not clearly established. For those with a healthy heart the American Heart Association (AHA) recommends fatty fish consumption twice a week. For individuals at risk for heart disease, when consuming EPA and DHA, research suggests a range of $0.5-1.8$ grams each day. If consuming the precursor, $A L A$, the recommended range is $1.5-3$ grams. Those with coronary heart disease (CHD) should consume 1 gram of EPA/DHA. To reduce elevated triglycerides (TAG) 2 - 4 grams a day should be consumed only under a doctor's supervision to monitor signs of toxicity (Kris-Etherton, et al., 2003). Some recommendations for intake are based on a specific ration of n-6:n-3 FAs.

Currently the U.S. population consumes a diet higher in n-6 FAs and lower in n-3 FAs than in the Paleolithic period (Simopoulos, 2006). The evolutionary human diet was about 1:1 (Simopoulos, 2006) and the current ratio is about 10 - 16.75:1 (Kris-Etherton, Harris and Appel, 2002 and Simopoulos, 2006). Consumption is expressed in grams per day is estimated to be 0.05 grams of DHA, 0.08 grams of EPA and 1.2 grams of ALA (Simopoulos, 2001).The high consumption of n-6 FAs may contribute to the increase in health problems because of the $n-2$ series eicosanoids that promote platelet aggregation and inflammation. This imbalanced intake reflects availability in the food supply and dietary intake.

It is estimated that the beneficial n-6:n-3 ratio is a $1: 1$ consumption ratio and that the current consumption is higher due to the increased use of n-6 rich oils (KrisEtherton, Harris and Appel, 2002). To correct the imbalance in the American diet, n-3 supplements can bring the ratio closer to the recommended 1:1. 
Supplements containing EPA and DHA, such as fish oil supplements, are known to cause some gastrointestinal discomfort for some. A supplement containing ALA may be a better option for those experiencing the discomfort (Escott-Stump, 2008). It is estimated that a higher amount of ALA, $1.5-3 \mathrm{~g} / \mathrm{d}$, would need to be consumed to achieve the same benefits as the EPA/DHA supplement (Kris-Etherton, Harris and Appel, 2002).

Omega-3 FAs are also essential for development of the eyes and brain of a fetus. A deficiency of n-3 FAs it may lead to cognitive dysfunction and poor mental health. Adequate consumption of n-3 FAs during pregnancy will aid in the development of the fetus. To continue the proper development, infants should consume n-3 FAs. If an infant is breast fed it is important that the mother continues to consume n-3 FAs. If the infant is formula fed, a formula with n-3 FAs should be selected.

EPA and DHA are naturally found in fatty fish such as mackerel, albacore tuna and salmon. ALA is a plant-based source of n-3 fatty acids. Tofu, walnuts, flaxseed and canola oil all contain ALA which can be converted to EPA and DHA in the body. Due to the limited sources of naturally occurring EPA and DHA, food products with added n-3 FAs are being developed and are part of a market section called functional foods.

Functional foods are defined as "foods with a physiological function or activity" that are "used for products containing biological active components at levels that may confer specific health benefits" (Knovel, 2005). Although production of functional foods is increasing there is no universal definition. Many organizations have provided definitions of functional foods but all agree that functional foods provide a health benefit 
(Hasler, 2002). EPA and DHA derived from fatty fish are the $n-3$ fatty acids most researched to be used as a functional food because of the benefits for heart, brain and eye health they appear to promote. One animal derived functional food containing n-3 FAs is the egg.

An average large egg contains provides around 70 calories and 13 essential vitamins and minerals (Incredible!, 2010). Eggs are a good source of protein that is inexpensive. One large egg has $7 \mathrm{~g}$ of protein, 4 of which are within the egg white. However, a whole egg also contains $5 \mathrm{~g}$ of fat and $213 \mathrm{mg}$ of cholesterol in the egg yolk (Brown, 2008). The Therapeutic Lifestyle Change (TLC) Diet recommends no more than $200 \mathrm{mg}$ of cholesterol a day to maintain a healthy heart (American Heart Association, 2006). One large egg a day would exceed the cholesterol limits of the TLC diet.

Feeding chickens a diet rich in n-3 FAs, such as menhaden oil, fish meal, flaxseed or canola oil, will allow for incorporation of the n-3 FAs into the egg itself and the cholesterol concentration may be reduced; however, cholesterol is not eliminated from the egg. The purpose of this study was to evaluate the sensory and quality parameters of a nutritionally-enhanced, low-cholesterol, post-laying, cooked egg product fortified with n-3 FAs over storage time. It is important to examine the proximate composition, $\mathrm{pH}$ changes, lipid oxidation, color changes and consumer likeability. 


\section{REFERENCES}

American Heart Association. (2006). Retrieved October 1, 2009, from American Heart Association: Learn and Live Web site: http://www.americanheart.org/presenter.jhtml?identifier $=4764$

Escott-Stump, Sylvia. Nutrition and Diagnosis - Related Care $6^{\text {th }}$ edition. (p. 404) (2008).

Hanebutt, Fabienne L., Demmelmair, Hans, Schiessl, Larque, Elvira, Koletzko, Berthold. (2008). Long-chain Polyunsaturated Fatty Acid (LC-PUFA) Transfer Across the Placenta. J. Clin. Nutr. 27, 685-693.

Hasler, Clare M. (2002). Functional Foods: Benefits, Concerns and Challenges - A Position Paper from the American Council on Science and Health. American Society for Nutritional Sciences.

Incredible!. (2010). Retrieved October 20, 2010, from Incredible! Web site: http://www.incredibleegg.org/health-and-nutrition/egg-nutrients.

Kris-Etherton, Penny, M., Harris, Williams S. and Appel, Lawrence J. (2002). Fish Consumption, Fish Oil, Omega-3 Fatty Acids and Cardiovascular Disease. Circulation. 106;2747-2757.

Kris-Etherton, Penny M., Harris, Williams S. and Appel, Lawrence J. (2003). Omega-3 Fatty Acids and Cardiovascular Disease New Recommendations From the American Heart Association. Arterioscler Thromb Vasc Biol. 23, 151-152.

Knovel Corporation. (2005). Dictionary of Food Science and Technology. (pp 157). The International Food Information Service.

Simopoulos, Artemis, P. (2001). N-3 fatty acids and human health: defining strategies for public policy. Lipids, 36;583-589.

Simopoulos, A. P. (2006). Evolutionary aspects of diet, the omega-6/omega-3 ratio and genetic variation: nutritional implications for chronic diseases. Biomedicine and Pharmacotherapy, 60, 502-507.

Simopoulos, Artemis P. (2008). The Importance of the omega-6/omega-3 Fatty Acid Ratio in Cardiovascular Disease and Other Chronic Diseases. The Society for Experimental Biology and Medicine. 


\section{CHAPTER II}

\section{REVIEW OF LITERATURE}

\section{HEALTH BENEFITS OF OMEGA-3 FATTY ACIDS}

Heart disease is the number one cause of death for men and women in the United States. One possible indication of inflammation that can increase the risk of myocardial infarction is high levels of $\mathrm{C}$ - reactive protein (C-RP) (Kelley, et al., 2008). Moderate risk levels are $1.0-3.0 \mathrm{mg} / \mathrm{L}$ and high risk levels are greater than $3.0 \mathrm{mg} / \mathrm{L}$ omega-3 (n-3) fatty acids (FA). It is possible to observe a significant reduction in C-RP levels in 6 months when consuming 6 grams of $n-3$ fatty acids daily (Bowden, et al., 2009).

High levels of serum triglycerides are also a risk factor for cardiovascular disease (CVD). Increased consumption of docosahexaenoic acid (DHA) and eicosanpentaenoic acid (EPA) enriched foods will lower triglyceride levels (Rose and Holub, 2006, Dawczynski, et al., 2010). The American Heart Association states that intake of n-3 FAs may also slow atherosclerotic plaque build-up, reduce abnormal heart rhythms and reduce the risk of blood clots that can lead to a stroke (Kris-Etherton, et al., 2010). High serum cholesterol has also been associated with increased risk of CVD. Though n-3 FAs only slightly decrease serum cholesterol levels (Kris-Etherton, et al., 2010) dietary cholesterol can increase serum cholesterol levels. Consuming approximately $120 \mathrm{~g}$ of standard whole eggs daily for less than 4 weeks can increase serum cholesterol (Roberts, McMurry and Conner, 1981).

Omega-3 FAs are beneficial when consumed by women prior to and during pregnancy. During pregnancy docosahexaenoic acid - lysophosphatidyl choline (DHA- 
LPC) is released from the liver. DHA-LPC delivers DHA to the placenta to help in fetal brain, central nervous system (CNS) and eye development (Valenzuela et al., 2010, Hanebutt et al., 2008). The most rapid fetal brain growth occurs during the final trimester of pregnancy. Preterm deliveries do not have the exposure to n-3 FAs at the crucial time period which leads to inferior development (Hanebutt et al., 2008).

Breast fed infants rely on the mother's consumption of n-3 FAs (Jensen, 1999). Maternal FA stores can be diminished during late pregnancy as the fetus develops (Bergmann et al., 2008). If there is no intake of DHA, breast milk could contain very little DHA. Normal breast milk contains $0.2-0.4 \%$ DHA (Jensen, 1999). With $200 \mathrm{mg}$ of DHA supplementation each day beginning in mid-pregnancy and continuing through lactation, breast milk can contain an average of $0.5 \%$ DHA (Bergmann et al., 2008). The group that did not receive the supplement in Bergmann's study had an average of only $0.25 \%$. This supports that theory that supplemental DHA intake can enhance the n-3 status of both the mother and the infant.

\section{NUTRITIONAL ENHANCEMENT OF EGGS}

Traditionally, changes in the nutritional composition of eggs were accomplished through diet manipulation. In an attempt to increase the $n-3$ content of eggs, hens were fed diets enriched with n-3 rich oils from marine, algae or oilseed sources. Up to $200 \mathrm{mg}$ of n-3 FAs were deposited in the yolk of the egg when fed a diet with $15-30 \mathrm{mg}$ of marine oil for each kilogram of feed (Van Elswyk, 1997). When the hens were taken off the high n-3 FA diets, a 20\% decrease in n-3 FA content of the egg yolks 1 week after n-3 FAs were not added to the hen feed. During the second week following removal of n-3 FAs from the feed, another $20 \%$ decrease was observed (Van Elswyk, 1997). The 
n-3 fatty acids are incorporated into the egg at the expense of some n-6 fatty acids (Van Elswyk, 1997) not the cholesterol.

Marshall and others reported an increase in n-3 FAs (Linolenic acid, DHA and EPA) with a decrease in n-6 FAs (arachidonic acid) when feeding hens $1.5 \%$ menhaden oil for 4 weeks (1994). The n-3 increase included a two-fold increase of alpha-linolenic acid (ALA) and a six-fold increase in DHA. EPA was not found in the control hen eggs but the treatment hen eggs contained $16 \mathrm{mg}$ per yolk. A reduction in the saturated fatty acids, palmitic (16:0) and stearic (18:0) was also observed in the treatment eggs (Marshall, Sams and Van Elswyk, 1994).

When flaxseed enriched feeds are given to hens, more n-3 fatty acid are incorporated into the egg yolks $(24 \mathrm{mg} / \mathrm{g}$ yolk when ground and $18 \mathrm{mg} / \mathrm{g}$ yolk when whole) than $15 \mathrm{mg}$ marine oil/ $\mathrm{kg}$ (9 mg/g yolk). The incorporation of $\mathrm{n}-3$ fatty acids seems to reach its maximum point within 4 weeks when fed the higher levels of $n-3$ rich diets. When the diet is discontinued, n-3 fatty acid levels reduce back toward base line (Van Elswyk, 1997).

Lipids in eggs function in flavor, mouthfeel, texture and emulsification capacity. When the fat level is reduced those parameters will be altered. When the lipid content of cheese is reduced a firmer, more rubbery texture is produced (Drake, et al., 1998). Increasing the amount of unsaturated fatty acids in an egg causes the yolk to become less firm when subjected to compression tests (Iglesias, et al., 2007). Reducing fat content in chocolate causes a higher viscosity and poor melting in the mouth (Do, et al., 2007). Overall changing the lipid composition changes the function and sensory 
attributes of food products. However, n-3 enriched eggs would contain the same amount of fat as a standard egg, maintaining consumer acceptability.

A nutritionally-enhanced cooked egg product was developed by Kassis and others (2010 A and $2010 \mathrm{~B})$. The experimental eggs were prepared by removing the egg yolks, and then adding n-3 rich oils (flaxseed, menhaden, algae and krill oils), annatto, freeze dried eggs and salt to the egg whites to mirror the proximate composition, color and texture of whole eggs. The liquid batters were poured into polycarbonate tubes and cooked in a microwave oven.

Proximate composition (crude protein, total fat, moisture and ash) of the experimental eggs matched that of a whole egg $(P<0.05)$. Though the total fat content of the experimental eggs matched that of a whole egg, the whole egg control had a much higher cholesterol content than the experimental eggs. Fatty acid analysis showed that the experimental eggs had a much higher n-3 FA content. The texture of the experimental eggs was not different than the whole egg $(P>0.05)$ but color differences were seen between the whole egg and the experimental eggs $(P<0.05)(K a s s i s$, et al., 2010 A). This method of nutritional-enhancement could yield a better result nutritionally than traditional enhancement by lowering cholesterol and adding high amounts of $n-3$ FAs.

\section{LIPID OXIDATION}

The change in lipid composition of an egg may affect the shelf life of the product, due to a different rate of lipid oxidation. The breakdown of lipids changes many aspects of food, from the color to $\mathrm{pH}$. Rancidity and off-odors and flavors may result. Egg yolks 
naturally contain vitamin $\mathrm{E}$, avidin and phosphatine which make a whole egg resistant to lipid oxidation (Pike and Peng, 1985). Whole eggs that are nutritionally-enhanced via chicken feed may be more susceptible to lipid oxidation because the eggs may contain a higher amount of very long-chain polyunsaturated fatty acids (VLCPUFAs), which are more readily oxidized than saturated fats (Marshall, Sams and Van Elswyk, 1994).

The first step in lipid oxidation is the formation of a free radical. Foods with unsaturated fatty acids are more susceptible to free radical formation. The available hydrogen ions bond with oxygen and perioxides are formed. Another unsaturated fatty acid donates a hydrogen atom. This produces a hydroperoxide with the initial fatty acid and another free radical from the donation of the hydrogen atom (McWilliams, 2005). The primary products of lipid oxidation include lipid hydroperoxides (LHP), which are further broken down into secondary products. To measure lipid oxidation of n-3 enhanced egg batters the secondary oxidation products, such as malondialdehyde $(\mathrm{MDH})$, should be measured (Galobart, et al., 2001).

Testing thiobarbituric acid reactive substances (TBARS) is a method commonly used to assess the amount of malondialdehyde (MDA) in a product. MDA is commonly used to measure lipid oxidation because it has a much longer half life the LHP. A higher value means more lipid oxidation has occurred. Over a 6-week storage time eggs of chickens fed varying levels of flaxseed and fish oil diets had increasing TBARS values (Scheideler, Froning and Cuppett, 1997). However, past week 6 of storage, TBARS levels decreased perhaps due to reactions with other chemical components within the egg (Scheideler, Froning and Cuppett, 1997). 


\section{SENSORY EVALUATION}

Consumers are displaying more demand for foods with health benefits (Childs and Poryzees, 1997). As consumers age they tend to become more concerned with the health benefits of foods than taste, opposite of young consumers (Roininen, Lähteenmäki and Tuorila, 1999). Sensory evaluations are a method to evaluate the acceptability of a food product. Just as consuming different types of feeds changes the lipid content of a hen's egg, taste, smell and appearance may also be altered.

When hens were fed $30 \mathrm{mg}$ of marine oil/kg of feed the hen eggs were perceived as fishy when eaten scrambled but not when eaten hard boiled at room temperature. Hens fed a $15 \mathrm{mg}$ marine oil/kg feed diet did not produce eggs that were perceived as fishy and were stable during storage time (Van Elswyk, 1997). A diet consisting of $1.5 \%$ menhaden fish oil or $5 \%$ flaxseed to enrich egg yolks produce an egg that is still acceptable by consumers (Scheideler, Froning and Cuppett, 1997 and Marshall, Sams and Van Elswyk, 1994). However, when flaxseed is increased to $10 \%$ and $15 \%$ of feed, a negative response to appearance and flavor was seen (Scheideler, Froning and Cuppett, 1997).

Some theorize that adding an antioxidant will reduce the off flavors that are associated with n-3 fatty acid enhancement. Eggs from hens fed $10 \%$ of their diet from flax seed and $10 \mathrm{mg}$ vitamin $\mathrm{E} / \mathrm{kg}$ of feed were perceived as fishy when compared to a control egg. However, when eggs from hens fed $20 \%$ flax and $10 \mathrm{mg}$ vitamin $\mathrm{E} / \mathrm{kg}$ of feed were compared to eggs of hens fed $20 \%$ flax and $100 \mathrm{mg}$ vitamin E $/ \mathrm{kg}$ of feed the off flavor was not noted (Leeson, Caston and Maclaurin, 1998). 
Tocopherol was used by Cherian and other (1996) to examine the extent of reducing lipid oxidation in eggs from hens fed diets containing different lipids. There was no difference in lipid oxidation over time between eggs from hens fed tocopherols and those that were not. However, hens that were fed tocopherols in addition to a diet rich in $n-3$ FAs had a higher amount of n-3 FAs than hens not fed tocopherols with the $n-3$ FAs. A possible explanation is that tocopherols protect the n-3 FAs from deterioration or tocopherols enhance the desaturase pathway and increases the synthesis of n-3 FAs (Cherian, Wolfe and Sim, 1996).

Hayat and others (2010) used $100 \mathrm{mg} / \mathrm{kg}$ feed butylated hydroxytoluene (BHT) or $100 \mathrm{IU} / \mathrm{kg}$ feed vitamin $\mathrm{E}$ ( $\alpha$-tocopherol) as antioxidants in feeds that contained $10 \%$ flax seed to maintain sensory qualities. Untrained sensory evaluators were unable to distinguish a difference among any of the samples taste or aroma. Trained sensory evaluators did find the enhanced eggs to have an off-flavor and a different aroma than the control eggs. The addition of antioxidants did not prevent off-flavors and aroma associated with lipid oxidation (Hayat, et al., 2010).

\section{MAINTAINING QUALITY PARAMETERS}

Raw eggs sold in the market are typically thermally pasteurized to prevent Salmonella enteritidis. However, about 19000 cases of food-borne illness still occur annually due contamination (Kamotani, et al., 2010). The majority of eggs sold as an already prepared item are packaged under modified atmospheres (MAP). These egg items have a pH around 7.7, a level suitable for bacterial growth (Clair, et al., 2004). The quality of this ready to eat, MAP eggs decreases over storage time and have a chance of post production contamination from handling during packaging and 
preparation (Clair, et al., 2004). Weight loss and changes in color and $\mathrm{pH}$ are important indicators quality deterioration (No, Prinyawiwatkul and Meyers, 2005), all which can decrease more rapidly if conditions allow bacterial growth.

A variety of packaging methods are used to prevent spoilage of already prepared hard boiled eggs. One method used is dipping prepared eggs, in shell or peeled, into edible chitosan-lysozyme composite coating (Kim, Daeschel and Zhao, 2008). Coating the eggs, with or without the shell, may maintain the color and slow loss of moisture and changes in $\mathrm{pH}$ (Kim, Daeschel and Zhao, 2008). Proper refrigeration of prepared egg products may be more important in maintaining quality than the packaging process (Clair, et al., 2004).

\section{TEXTURE PROFILE ANALYSIS (TPA)}

The application of heat or cooking an egg denatures the proteins and causes a gel to form. The temperature of the egg will increase very rapidly until the gel begins to form at $60-65^{\circ} \mathrm{C}$. At this point, approximately 4 minutes into cooking, the protein ovotransferrin will denature. The temperature of the egg will increase very slowly until it reaches $80-85^{\circ} \mathrm{C}$. Ovalbumin will denature and strengthen the gel causing the entire egg to firm and hold a shape (Woodward and Cotterill, 1987 and Croguennec, Nau and Brulé, 2002).

Many factors contribute to the texture profile of a cooked egg. When an egg is hard-boiled in shell without disrupting the yolk, the yolk texture will be dry and crumbly. If an egg yolk is disrupted and mixed with the egg while the texture will be springy and hard when the egg is cooked (Woodward and Cottrill, 1987). Woodward and Cottrill 
(1987) found that the hardness of an egg will increase if $\mathrm{pH}$, temperature, time exposed to heat, concentration of protein or concentration of salt is increased (Woodward and Cotterill, 1987). As an egg ages, it becomes more basic, meaning older eggs will naturally form a harder gel (Croguennec, Nau and Brulé, 2002). A pH ranging from 7 to 9 will form a more uniform gel due to the smaller spaces between the aggregates, negative net charge and slower thermocoagulation leading to higher water-holding capacity and more viscoelasticity (Croguennec, Nau and Brulé, 2002). Many have stated that as salt concentration increases the gel will become harder up to $0.05 \mathrm{M} \mathrm{NaCl}$ (Woodward and Cotterill, 1987 and Croguennec, Nau and Brulé, 2002). Concentration levels above this have very little additional effect.

\section{SUMMARY}

Nutritional enhancement of eggs via alterations in chicken feed is likely to increase n-3 FA content as long as feeding is maintained. Sensory changes from nutritional enhancement eggs using flax is possibly the least detected source of n-3 fatty acids. It is unclear if the use of antioxidants will stave off lipid oxidation and preserve the sensory qualities of the eggs. The amount of fat is not altered just the type of fats allowing them to function the same as a standard egg (Pankey, 1969). It appears that the incorporation of the n-3 FA is in place of n-6 FA and not of saturated fats or cholesterol (Marshall, Sams and Van Elswyk, 1994). For that reason, altering feed to enhance chicken eggs may not provide maximal health benefits.

Enhancement of the eggs after laying by removal of egg yolks may be a better method. This method would eliminate the saturated fat and cholesterol from the egg and add n-3 FAs. Eggs are a staple item; being one of the top 25 foods to contribute to daily 
calorie consumption, and in the top 15 of foods that contribute to saturated fat and cholesterol consumption in the average U.S. American diet (National Cancer Institute, 2010), a lipid altered egg product could lead to a decrease in saturated fat and an increase in n-3 FA consumption on a population level. Therefore, the purpose of this study was to evaluate the sensory and quality parameters of a nutritionally-enhanced, low-cholesterol, post-laying, cooked egg product fortified with n-3 FAs over storage time. It is important to examine the proximate composition, $\mathrm{pH}$ changes, lipid oxidation, color changes and consumer likeability. 


\section{REFERENCES}

Bergmann, Renate L., Haschke-Becher, Elisabet, Klassen-Wigger, Petra, Bergmann, Karl E., et al. (2008) Supplementation with 200 mg/day DHA From Mid-Pregnancy Through Lactation Improves DHA Status of Mothers with Habitually Low Fish Intake and Their Infants. Annals of Nutr. and Metabolism, 52, 157-166.

Bowden, Rodney G., Wilson, Ronald L., Delke, Erica and Gentila, Mindy. (2009) Fish Oil Supplementation Lowers C-Reactive Protein Levels Independent of Triglyceride Reduction in Patients with End-Stage Renal Disease. Nutr Clin Pract, 24, 508.

Cherian, G., Wolfe, F. H. and Sim, J. S. (1996). Feeding Dietary Oils with Tocopherols: Effects on Internal Qualities of Eggs During Storage. J Food Sci. 61:15-18.

Childs, Nancy M. and Poryzees, Gregg H. (1997). Foods that help prevent disease: consumer attitudes and public policy implications. J of Consumer Marketing. 14:433447.

Claire, Benoît, Smith, James P., El-Khoury, Wassim, Cayouette, Bernard, Ngadi, Michael, Blanchfield, Burke, Austin, John W. (2004) Challenge Studies with Listeria monocytogenes and Proteolytic Clostridium botulinum in Hard-boiled Eggs Packaged Under Modified Atmospheres. Food Microbiology, 21:131-141.

Croguennec, T., Nau, F. and Brulé G. (2002). Influence of pH and Salts on Egg White Gelation. J Food Sci. 67:608-614.

Dawczynski, Christine, Martin, Lena, Wagner, Andreas, Jahreis, Gerhard. (2010). n-3 LC-PUFA-enriched dairy products are able to reduce cardiovascular risk factors: A double-blind, cross-over study. Clinical Nutrition 1-8.

Do, T-A. L., Hargreaves, J. M., Wolf, B., Hort, J. and Mitchell, J. R. (2007). Impact of Particle Size Distribution on Rheological and Textural Properties of Chocolate Models with Reduced Fat Content. J Food Sci. 72(9):E541-E552.

Drake, M. A., Chen, X. Q., Gerard, P. D. and Gurkin, S. U. (1998) Composition and Quality Attributes of Reduced-Fat Cheese as Affected by Lecithin Type. J Food Sci. 63(6):1018-1023.

Galobart, J., Barroeta, A. C., Baucells, M. D. and Guardiola, F. (2001). Lipid Oxidation in Fresh and Spray-Dried Eggs Enriched with $\omega 3$ and $\omega 6$ Polyunsaturated Fatty Acids During Storage as Affected by Dietary Vitamin E and Canthaxanthin Supplementation. Poultry Science, 80, 327-337. 
Hanebutt, Fabienne L., Demmelmair, Hans, Schiessl, Larque, Elvira, Koletzko, Berthold. (2008). Long-chain Polyunsaturated Fatty Acid (LC-PUFA) Transfer Across the Placenta. J. Clin. Nutr. 27, 685-693.

Hayat, Z., Cherian, G., Pasha, T. N., Khattak, F. M. and Jabbar, M. A. (2010). Sensory evaluation and consumer acceptance of eggs from hens fed flax seed and 2 different antioxidants. Poultry Science 89:2293-2298.

Jensen, Robert G. (1999) Lipids in Human Milk. Lipids. 1243-1271.

Juliano, Pablo, Li, Biansheng, Clark, Stephanie, Mathews, Jason W., Dunne, Patrick C. and Barbosa-Canovas, Gustavo V. (2006). Descriptive Annalysis of Precooked Egg Products After High-Pressure Processing Combined with Low and High Temperatures. Journal of Food Quality. 29:505-530.

Kamotani, Setsuko, Hooker, Neal, Smith, Stephanie and Lee, Ken. (2010). Consumer Acceptance of Ozone-Treated Whole Shell Eggs. J Food Sci. 75(2):S103-S107.

Kassis, Nissan, Drake, Sara R., Beamer, Sarah K., Matak, Kristen E. Jaczynski, Jacek. (2010). Development of nutraceutical egg products with omega-3-rich oils. LWT - Food Science and Technology. 43:777-783.

Kassis, Nissan, Beamer, Sarah K., Matak, Kristen E., Tou, Janet C. and Jaczynski, Jacek. (2010). Nutritional composition of novel nutraceutical egg products developed with omega-3-rich oils. LWT - Food Science and Technology. 43:1204-1212.

Kris-Etherton, Penny M., Harris, William S., Appel, Lawrence J. and the AHA Nutrition Committee. (2010). Omega-3 fatty acids and cardiovascular disease: new recommendations from the American Heart Association. American Heart Association Journal.

Kelley, Darshan S., Siegel, David, Fedor, Dawn M. et al. (2007) DHA Supplementation Decreases Serum C-Reactive Protein and Other Markers of Inflammation in Hypertriglyceridemic Men. J. Nutr., 139, 495-501.

Kim, K.W., Daeschel M. and Zhao, Y. (2008). Edible Coating for Enhancing Mirbrobial Safety and Extending Shelf Life of Hard-Boiled Eggs. Food Microbiology and Safety. 73:M227-M235.

Leeson, S., Caston L. and Maclaurin T. (1998). Organoleptic Evaluation of Eggs Produced by Laying Hens Fed Diets Containing Graded Levels of Flaxseed and Vitamin E. Poultry Science, 77:1436-1440. 
Marshall, A. C., Sams, A. R. and Van Elswyk, M. E. (1994). Oxidative Stability and Sensory Quality of Stored Eggs From Hens Fed 1.5\% Menhaden Oil. J Food Sci. 59:561-563.

McWilliams, M. Foods Experimental Perspectives $5^{\text {th }}$ ed. (pp 403, 264) (2005). Upper Saddle River, NJ. Pearson Prentice-Hall, Inc.

Meilgaard, Morten C., Civille, Gail Vance, Carr, B. Thomas. (2007). Sensory Evaluation Techniques. Florida: CRC Press.

National Cancer Institute. (2010). Retrived on February 16, 2011 from the National Cancer Institute website: http://riskfactor.cancer.gov/diet/foodsources/.

No, Hong Kyoon, Prinyawiwatkul, Witoon and Meyers, Samuel P. (2005). Comparison of Shelf Life of Eggs Coated with Chitosans Prepared Under Various Deproteinization and Demineralization Times. J Food Sci 70:S377-82.

Pankey, R. D. and Stadelman. (1969). Effect of dietary fats on some chemical and functional properties of eggs. J Food Sci. 34:312-317.

Pike, O. A. and Peng, I. C. (1985). Stability of Shell Egg and Liquid Yolk to Lipid Oxidation. Poultry Science. 64: 1470-1475.

Roberts, Susan L.M.S., R.D., McMurry, Martha, M.S., R.D. and Connor, William E., M.D. (1981). Does egg feeding (i.e., dietary cholesterol) affect plasma cholesterol levels in humans? The results of a double-blind study. Am. J. Clin. Nutr. 24:2092-2099.

Roininen, K., Lähteenmäki, L. and Tuorila, H. (1999). Quantification of consumer attitudes to health and hedonic characteristics of foods. Appetite 33:71-88.

Rose, Emily L. and Holub, Bruce J. (2006). Effects of a liquid egg product containing fish oil on selected cardiovascular disease risk factors: A randomized crossover trial. J Food Research International 39:910-916.

Scheideler, S. E., Froning, G., Cuppett, S. (1997). Studies of Consumer Acceptance of High Omega-3 Fatty Acid-Enriced Eggs. J. Appl. Poultry Res. 6:137-146.

Valenzuel, Alfonso, Neito, Susana, Sanhueza, Julio, Morgado, Rojas, Ingrid and Zanartu, Patricia. (2010). Supplementing Female Rats with DHAlysophosphatidylcholine Increases Docosahexaenoic Acid and Acetylcholine Contents in the Brain and Improves the Memory and Learning Capabilities of the Pups. Grasas $Y$ Aceites. 61 (1), 16-23. 
Van Elswyk, Mary E. (1997). Comparison of n-3 Fatty acid Sources in Laying Hen Rations for Improvement of Whole Egg Nutritional Quality: a Review. British J. of Nutr. 78:S61-S69.

Woodward, S. A. and Cotterill, O. J. (1987). Testure Profile Analysis, Expressed Serum, and Microstructure of Heat-Formed Egg Yolk Gels. J Food Sci 52:68-74. 


\section{CHAPTER III}

Sensory Evaluation and Quality Indicators of Nutritionally Enhanced Egg Product with Omega-3 Rich Oils. 


\begin{abstract}
Heart disease is a leading cause of death in the United States. Omega-3 (n-3) fatty acids (FA) positively affect heart health while high levels of cholesterol are an indication of poor heart health. Nutritionally-enhanced, low-cholesterol egg sticks fortified with n-3 FA were developed; quality indicators measured and sensory evaluations conducted. Store-bought eggs were separated and egg whites mixed with oil, spray dried egg whites, annatto (color) and salt. The oil sources included: algae, menhaden, flaxseed, and canola oils. Experimental egg batters and mixed whole egg (control) were cooked in the shape of a cheese stick, vacuum packed, and stored at 4C. Quality indicators (color $\left(\mathrm{L}^{*}, \mathrm{a}^{*}, \mathrm{~b}^{*}\right)$, texture, $\mathrm{pH}$ and lipid oxidation) of egg sticks were measured over a storage period of 14-d. There were no changes in color over time $(P>0.05)$; however, whole egg was significantly less red and yellow compared to experimental eggs $(P<0.05)$. Significant differences in texture properties were observed $(\mathrm{P}<0.05)$ but these were independent of time $(\mathrm{P}>0.05)$. A difference in $\mathrm{pH}$ between egg types was seen $(\mathrm{P}<0.05)$; however, the $\mathrm{pH}$ for each egg type did not change over time $(P>0.05)$. No trend in lipid oxidation was seen over storage time $(P>0.05)$. Egg sticks were evaluated by a consumer panel of 56 participants for color, odor, flavor, texture between fingers, mouth feel and overall liking with a 9-point scale (1=dislike extremely; $9=$ like extremely). Panelists also ranked samples from most to least liked. The texture between fingers of the whole egg was significantly more liked than the experimental eggs containing DHAS and canola oils $(\mathrm{P}<0.05)$. Odor scores were significantly greater $(P<0.05)$ in whole egg compared to the experimental egg containing flaxseed oil. No significant preference was observed in mouthfeel or flavor. All samples were well-liked,
\end{abstract}


with a combined average score of 5.9. Ranking results support this conclusion with no significant differences in preference $(P>0.05)$. The results indicate that the experimental eggs are accepted by consumers on the same level as mixed whole eggs and may have potential as a marketable product.

Key words: Omega-3, Egg, TBARS, texture profile analysis, functional food, egg composition, sensory evaluation 


\section{Introduction}

Animal protein is an excellent source of amino acids essential to building body proteins due to their high bioavailability. However, sources of animal protein tend to be high in saturated fat which is associated with higher risks of cardiovascular disease. The trend of consumer demands is heading toward foods with more health benefits, such as those foods containing omega-3 (n-3) fatty acids (FA) because of the association with lower risks of several health complications such as inflammatory diseases (Bou, et al., 2009).

Though a current recommendation does not exist for the amount of n-3 FAs that should be consumed, a suggested ratio of omega-6 (n-6):n-3 FAs does. A 1:1 ratio is thought to be the most beneficial to human health; however, the current n-6:n-3 FA ratio consumed by U.S. American's is much higher, about 10 - 16.75:1 (Kris-Etherton, Harris and Appel, 2002 and Simopoulos, 2006). This is likely due to the availability of more n-6 FA containing foods for consumption.

Eggs are a staple protein source in the American diet; they are one of the top 25 foods eaten and contribute $11 \%$ to daily calorie consumption (National Cancer Institute, 2010 and Drewnowski, 1995). Though they are a good source of protein, eggs are also in the top 15 of foods that contribute to saturated fat and cholesterol intake (National Cancer Institute, 2010). Given the high contribution to a typical diet, formulating an egg product that is low in saturated fat, cholesterol-free and nutritionally enhanced with more n-3 FAs could be beneficial. 
Enriching eggs with n-3 FAs is typically accomplished by increasing the n-3 FA content in the feed given to hens. Hens are able to incorporate the dietary n-3 FAs into the fat composition of the egg yolks (Bout, et al., 2009). Typical oils added to an egglaying hen's diet include: marine algae (Van Elswyk, 1997), menhaden oil (Marshall, Sams and Van Elswyk, 1994, Scheideler, Froning and Cuppett, 1997 and Van Elswyk, 1997) and flaxseed oil (Van Elswyk, 1997 and Scheideler, Froning and Cuppett, 1997), with each differing in the amount of n-3 FA incorporation into the egg yolk.

When feed supplemented with $24 \mathrm{~g}$ marine algae/kg feed was fed to hens for four weeks, $9.5 \mathrm{mg} \mathrm{n}-3 \mathrm{FA} / \mathrm{g}$ yolk was incorporated into the egg (Van Elswyk, 1997). The maximum beneficial amount of marine algae is suggested to be between 24 and 48 $\mathrm{g} / \mathrm{kg}$ feed because when hens were fed $48 \mathrm{~g} / \mathrm{kg}$ feed the total $\mathrm{n}-3 \mathrm{FA}$ incorporation did not double but increased to $12.2 \mathrm{mg} \mathrm{n}-3 \mathrm{FA} / \mathrm{g}$ yolk (Van Elswyk, 1997). Eggs of hens fed 25 - $30 \mathrm{~g}$ menhaden oil/kg feed reached a plateau of n-3 FA incorporation, 200 $\mathrm{mg} /$ yolk, after 3 weeks of feeding (Van Elswyk, 1997). The menhaden oil contains more EPA than DHA; however DHA was the primary n-3 FA deposited in the egg yolk. About $89 \%$ of the consumed DHA was incorporated into the egg yolk while less than $5 \%$ of the EPA consumed was in the egg yolk. N-3 FAs were incorporated; however, significant reductions of n-3 FAs in the egg yolks were reported 4 weeks after the diet ceased. The increase in n-3 FAs was at the expense of n-6 FAs, not cholesterol (Van Elswyk, 1997). Consumer's found eggs from hens receiving $30 \mathrm{~g}$ menhaden oil/ $/ \mathrm{kg}$ feed acceptable when hard boiled, but reported fishy flavors when eggs were scrambled (Van Elswyk, 1997). When $150 \mathrm{~g}$ of ground flaxseed/kg feed was given to hens, each gram of yolk contained 24 mg n-3 FAs (Van Elswyk, 1997). The primary n-3 FA incorporated into the 
yolk was linolenic acid, which is considered less bioactive (Van Elswyk, 1997). Flaxseed oil incorporated into a hen's diet at a level of $5 \%$ of the feed were acceptable to consumers, but when the feed was $10-15 \%$ flaxseed oil, negative sensory attributes were seen in appearance and flavor (Scheideler, Froning and Cuppett, 1997).

Adding n-3 FAs to eggs after production may yield more consistent results. Kassis and others developed an n-3 enriched egg product (2010b) by egg yolk removal and incorporation of n-3 FA rich oils into the egg whites. Freeze-dried egg whites were included to replace the protein lost with the yolk. The proximate composition (crude protein, total fat, moisture and ash) were similar to that of a whole egg control (Kassis, et al. 2010b). The total fat of the experimental eggs contained a greater amount of $n-3$ FAs and significantly less cholesterol and saturated fat than the whole egg $(P<0.05)$ (Kassis, et al., 2010b). Therefore, the purpose of this study was to evaluate the sensory and quality parameters of a nutritionally-enhanced, low cholesterol, ready-to-eat (RTE) egg product similar those developed by Kassis et al. (2010 a and b) over storage time. Proximate composition, $\mathrm{pH}$ changes, lipid oxidation, color changes and consumer likeability will be examined. 


\section{MATERIALS AND METHODS}

\section{Preparation of egg products}

Nutritionally-enhanced egg sticks were formulated based on the findings of Kassis and others (2010a, 2010b). The yolks of fresh eggs purchased at a local grocery store in the refrigerated section were hand-separated to yield $430 \mathrm{ml}$ of egg whites. The target macronutrient composition of the batters was to be similar to a whole egg; therefore, to replace the protein removed with the egg yolk, the egg whites were handmixed for 10 min with $15 \mathrm{~g}$ of powdered egg whites (Honeyville Farms Powdered egg whites, Sherrco Products Honeyville, Utah). The mixture was stored in a foil covered beaker overnight at $4{ }^{\circ} \mathrm{C}$ to allow for complete hydration of the powdered egg whites. Once the dried egg whites were rehydrated and dispersed in the egg white mixture, 50 $\mathrm{ml}$ of the following oils were used in the formulation of the experimental egg batters:

1. Canola oil from Kroger (Morgantown, WV).

2. Flaxseed oil from Jedwards International, Inc. (Quincy, MA).

3. Menhaden oil (Omega Pure 8042TE) from Omega Pure (Reedsville, VA).

4. Algae oil (DHAS) from Martek Biosciences (Columbia, MD).

5. Blend of $30 \mathrm{ml}$ flaxseed, $10 \mathrm{ml}$ DHAS and $10 \mathrm{ml} \mathrm{krill} \mathrm{oil} \mathrm{(4225F)} \mathrm{from}$ Enzymotec USA, Inc. (Springfield, NJ).

In addition to the oils, $750 \mu \mathrm{l}$ Annatto (for color) and $5 \mathrm{~g}$ of $\mathrm{NaCl}$ (table salt) were added to the egg whites. The volume of the batters was approximately $500 \mathrm{ml}$. The batters were stirred on a stirring plates (Fisher Scientific Thermix Stirrer model 120S) 
set at medium speed with a magnetic stir bar for $2 \mathrm{~h}$ in a standard $1000 \mathrm{ml}$ glass beaker. Temperature was maintained at $4^{\circ} \mathrm{C}$ by wrapping the beaker with bags of ice.

\section{Cooking of omega-3 enhanced egg batters}

Immediately after stirring, approximately $50 \mathrm{ml}$ of the batter were poured into polycarbonate tubes $($ length $=18 \mathrm{~cm}$, internal diameter $=1.90 \mathrm{~cm}$, wall thickness $=$ $0.635 \mathrm{~cm}$ ) lightly sprayed with cooking spray (Kroger brand Vegetable oil cooking spray) to prevent sticking, and sealed with screw caps. Tubes were submerged in a standard stainless steel stockpot of boiling water for 10 min. After cooking, tubes were cooled in ice water, the cooked egg sticks were removed from the tubes, patted dry with disposable towels, vacuum-packed and stored at $4{ }^{\circ} \mathrm{C}$ until analyses were conducted.

\section{Analysis on Cooked Egg Sticks}

Proximate Composition: Proximate composition (moisture, fat, protein and ash) of cooked experimental egg stick containing the oil blend was determined according to the Association of Official Analytical Chemists methods (1995) and is be expressed as $\mathrm{g} / 100 \mathrm{~g}$ (wet basis). Moisture was determined by spreading $2 \mathrm{~g}$ of sample in aluminum dishes (Fisher Scientific Co., Fairlawn, NJ) and drying them at $105^{\circ} \mathrm{C}$ for $24 \mathrm{~h}$. The Soxhlet extraction method and Kjeldahl assay were used to determine fat and crude protein content, respectively. Ash was determined by ground sample being placed in porcelain crucibles and incinerated at $550^{\circ} \mathrm{C}$ for 24 hours.

pH: Changes in $\mathrm{pH}$ were measured over a two-week storage period, based on a targeted retail shelf-life. The $\mathrm{pH}$ of each prepared egg stick was tested using the $\mathrm{pH} / \mathrm{ion}$ 
analyzer (Model 350, Corning Inc.; Corning NY, USA) by placing the probe against the surface of the egg stick. The samples were tested on days $0,2,4,6,8$ and 14 .

Color: Color differences and changes of each egg stick were measured over time using a chromameter (Model CR-300; Minolta Camera Co. Ltd., Osaka Japan) calibrated with a standard white plate No.21333180 (CIE L 93.1; $a^{*} 0.3135 ; b^{*} 0.3198$ ). Color was measured based on lightness $(\mathrm{L})$, amount of red $\left(\mathrm{a}^{*}\right)$ and amount of yellow $\left(b^{\star}\right)$. The samples were tested on days $0,2,4,6,8$ and 14 .

Syneresis: The amount of water loss from the cooked egg products, or syneresis, was calculated using the following equation by Juliano and others (2006a):

$\%$ weight loss $=[($ initial weight - final weight $) /$ initial weight $] \times 100 \%$

The \% weight loss was calculated for each sample on each day of the storage period (days $0,2,4,6,8$ and 14 ).

Testing thiobarbituric acid reactive substances (TBARS): TBARS were completed in order to assess the lipid oxidation of the unsaturated fatty acids within the egg sticks. The oxidation of unsaturated fatty acids creates carbonyl compounds giving an unpleasant or rancid taste. Lipid oxidation was assessed by measuring the color absorbance at $535 \mathrm{~nm}$. The specific compound created by oxidation that will be tested using TBARS is malondialdehyde, a dicarbonyl compound as explained by Yu and Sinnhuber (1957).

Texture Profile Analysis (TPA): Texture profile analysis (TPA) was performed on the egg sticks in triplicate at room temperature. Samples (length $=2.54 \mathrm{~cm}$, diameter 
$=1.90 \mathrm{~cm}$ ) were brought to room temperature and subjected to a two-cycle $50 \%$ compressions using a texture analyzer (Model TA-HDi, Texture Technologies Corp., Scarsdale, NY) in likeness of Cheret and others (2005). A 70-mm TPA compression plate was attached and was set to move at $120 \mathrm{~mm} / \mathrm{min}$. Hardness, springiness, cohesiveness, gumminess, chewiness and resilience were determined from the recorded force-time curves (Chen and Jaczynski, 2007a; 2007b; Taskaya et al., 2009a; 2009b; 2009c). Hardness is the peak force needed to compress the sample.

Springiness is the ability to recover the original form after force ceases. Cohesiveness is the degree the sample can be deformed before it breaks. Gumminess is hardness $\mathrm{x}$ cohesiveness. Chewiness is springiness $x$ gumminess. Resilience is how much the sample opposes the force to return to its original shape (Kassis, et al., 2010a).

Microbial Analysis: The microbial load of the egg sticks were assessed over the storage period. Ten $\mathrm{g}$ of prepared egg sample were placed in a filtered stomacher bag with $90 \mathrm{~mL}$ of deionized, distilled water. Samples were pulverized using a stomacher until evenly distributed in the water. Using a micropipette $0.1 \mathrm{~mL}$ was spread-plated onto Xylose Lysine Deoxycholate (XLD; Remel, Lenexa, KS, USA) agar plate and 0.1 $\mathrm{mL}$ was spread-plated to a Trypticase Soy Agar (TSA; Difco, Becton Dickinson, Sparks, MD) plate. XLD was used specifically to monitor for Salmonella spp. contamination and the TSA was used to determine if any other bacterial contamination has occurred. Microbial analysis was conducted on days $0,2,4,6,8$ and 14 . The plates were incubated (Fisher Scientific low temperature incubator) at $35^{\circ} \mathrm{C}$ for $24-48$ hours and the number of colonies were counted.

\section{Sensory evaluation}


Sample preparation: Egg sticks formulated with menhaden oil had a noticeable fish odor and egg sticks formulated with the oil mixture (1\% DHAS, $1 \%$ krill oil and $8 \%$ flaxseed oil) presented with an unnaturally red color due to astaxanthin in the krill oil. Therefore, only egg sticks formulated with DHAS oil, flaxseed oil, canola oil and whole egg were tested during the sensory evaluation. Samples were prepared as described above, cut into 1-cm "coins" and placed into soufflé cups with lids coded with a random 3-digit code. The concept of the egg product was to mimic a hard-boiled eggs, which are often eaten cold; therefore samples were held at $4{ }^{\circ} \mathrm{C}$ until sensory evaluation was conducted.

Consumer panel participant selection: Fifty six adults over the age of 18 were recruited from the West Virginia University Davis College of Agriculture, Natural Resources and Design and were screened for food allergies.

Evaluations: Sensory evaluations were held in a well-lit, white colored room in the Test Kitchen and Foods Lab at West Virginia University. Prior to testing, participants were given a brief orientation on the testing methods and were required to read an informational hand-out (Appendix A) approved by the Institutional Review Board at West Virginia University. Participants were then asked to complete a pre-testing questionnaire (Appendix B) designed to assess the panelist demographics and to evaluate egg consumption.

Attribute testing: After completing the pre-testing questionnaire, participants were presented with one set of 4 samples in a balanced randomized order and asked to rate each sample on a 9-point hedonic scale where $1=$ dislike extremely and $9=$ like 
extremely (Appendix C). Panelists were asked to evaluate the samples in the order they were laid out for them from left to right. They were asked to evaluate the sample odor when the lid was first removed, followed by visual color, texture between fingers, then flavor, mouth feel and overall liking. Space was provided on the scorecards for comments on each attribute. Panelists were instructed to cleanse their palates between samples by tasting unsalted crackers and rinsing their mouth with room temperature water.

Ranking test: A second set of the same 4 samples coded with different 3-digit codes, was presented to the panelists in a balanced, randomized order. They were instructed to taste all sample in the order provided and to rank them from most liked to least liked (Appendix D). Panelists were offered the option of going back and repeating the evaluation of each sample in the order of presentation, while the test was in progress.

Statistical analysis: The storage study was replicated three times. All storage evaluations (color, $\mathrm{pH}$, texture profile; TPA) were performed in triplicate. Two measurements were completed for proximate analysis (protein, total fat, ash and moisture) and fatty acids. Thiobarbituric acid reactive substannces (TBARS) analysis was completed by blending triplicates and three measurements were taken of each sample. A $6 \times 6$ factorial experiment in a completely randomized design was used and the data were analyzed using ANOVA where the two factors were Time with levels 1, 2, 4, 6, 8 and 14 days and Egg Type with 6 levels (whole egg, canola, flax, menhaden, DHAS algae and blend). The relationship between color, surface $\mathrm{pH}$, texture and TBARS and time was examined via simple linear regression. Sensory evaluation 
responses from 56 participants were also analyzed. Tukey's Honestly Significant Differences Test $(P<0.05)$ was completed to analyze mean separation. All data were analyzed using JMP 8 software (SAS Institute, Cary, NC, USA). 


\section{Proximate analysis}

\section{RESULTS AND DISCUSSION}

The moisture content $(77.7 \pm 0.0)$, crude protein $(12.8 \pm 0.5)$, ash $(0.7 \pm 0.0)$ and fat content $(10.3 \pm 0.5)$ of the experimental egg containing the oil blend (Flaxseed, DHAS and Krill oils in an 8:1:1 ratio) was consistent with the findings of Kassis and others (2010a).

\section{Surface pH}

The $\mathrm{pH}$ of each sample did not significantly change over the storage time $(\mathrm{P}>$ 0.05) (Table 1). Fresh eggs have a $\mathrm{pH}$ ranging from $7.6-8.5$ with saturated levels of $\mathrm{CO}_{2}$, mainly in the form of bicarbonate (Banerjee, Keener and Lukito, 2011 and Kim, Daeschel and Zhao, 2008). Bicarbonate can act as an acid or a base and contributes to $\mathrm{pH}$ levels. Over time, $\mathrm{CO}_{2}$ escapes from the shell resulting in less bicarbonate in the egg and $\mathrm{pH}$ increases. The release of $\mathrm{CO}_{2}$ seems to effect the $\mathrm{pH}$ of hardboiled eggs as well. When a peeled hardboiled egg was coated with a chitosan-lysozyme composite a slower change in $\mathrm{pH}$ than an uncoated hardboiled egg was observed over a 10 week storage period (Kim, Daeschel and Zhao, 2008). Peeled and vacuum packed hardboiled eggs also had less change in $\mathrm{pH}$ over time (Kim, Daeschel and Zhao, 2008). Both methods reduced the amount of CO2 lost (Kim, Daeschel and Zhao, 2008). The experimental eggs were vacuum packed in a non-gas permeable package that likely contributed to the $\mathrm{pH}$ stability over the two week storage time by controlling the loss of $\mathrm{CO}_{2}$

\section{Color analysis}


Color values $\left(L^{*}, a^{*}, b^{*}\right)$ on prepared egg samples over storage time are reported in Tables 2 - 4. No significant changes were seen over the two week storage time $(P>0.05)$; however, significant differences in color were seen between the samples $(P<0.05)$. A grey scale value, $L^{*}$, represents the measurement of light reflected and light absorbed. $L^{*}$ values range from 0 to 100 ; where $0=$ black and $100=$ white. The experimental egg containing a blend of oils had a significantly lower $L^{*}$ value than all other eggs throughout the storage time $(P<0.05)$, meaning they were darker in color than all other eggs. This was consistent with the findings of Kassis, et al. that the experimental egg containing krill oil was the significantly darkest sample (2010a).

A positive $a^{*}$ value represents reddish hues and a negative $a^{*}$ value, greenish hues. Kassis and other showed a very high $a^{*}$ value when using krill oil (2010a). The amount of krill oil was reduced in attempt to eliminate the unnatural appearing red color. However, the experimental egg containing the blend of oils (krill, DHAS and flax) had a significantly higher $\mathrm{a}^{*}$ value $(\mathrm{P}<0.05)$ than all other samples throughout the storage time. By reducing the amount of krill in the experimental egg the redness of the sample was reduced to 23 or less from that of Kassis, et al. at 37.5 (2010a). The whole egg was significantly $(P<0.05)$ different than all experimental eggs with a negative $a^{*}$ value, numerically showing the greenish tent to the whole egg sample. This is a common color produced in hard-boiled, in shell eggs that are cooled slowly around the surface of the egg yolk due to ferrous sulfide production.

A positive $b^{*}$ value represents yellowish hues and a negative $b^{*}$ value, bluish hues. On days $0,2,4$ and 8 all experimental eggs had a significantly higher $b^{*}$ score than the whole egg $(P<0.05)$. This gives a numeric value to the visibly more yellow 
color in experimental eggs than the whole egg. On days 6 and 14 DHAS experimental eggs were not significantly different from other experimental eggs or the whole eggs ( $P$ $>0.05)$. This could be explained by the random sampling and inconsistent distribution of oils and annatto throughout the samples.

\section{Syneresis}

Syneresis is the loss of water from a gel. The experimental eggs had no significant changes in water loss over time $(P>0.05)$ but there were changes with the whole egg over time $(P<0.05)($ Table 5). Linear regression showed no interaction between time and percent of weight loss $(P>0.05)$; however, significant differences were seen in the percent weight loss between samples $(P<0.05)$. Given that the whole egg generally had the least amount of weight loss; it is likely that a natural emulsifier, lecithin, which is present in the yolk, had an effect on the water holding capabilities. Addition of an emulsifier to the experimental egg batters may have allowed for better distribution of water, protein and fat leading to less water loss over time. Juliano and others (2006b) reported that xanthan gums reduced the amount of water loss in cheese; the water holding capabilities of the experimental eggs may also be improved with the addition of xanthan gum.

\section{Testing thiobarbituric acid reactive substances (TBARS)}

Lipid oxidation typically occurs at a much faster rate in n-3 FA containing foods resulting in a higher concentration of MDA. Although there were significant changes in MDA concentration for each experimental egg product $(P<0.05)$ over the course of the 14-day period, linear regression showed no correlation of time and lipid oxidation (Table 
6). Reactions with other chemical components within the egg may have caused the inactivation of oxidation products resulting in the observed decreases of MDA on days after day 0 (Scheideler, Froning and Cuppett, 1997).

\section{Texture Analysis (TPA)}

Texture profile analysis data are presented in Tables 7 -12. Data show that textural integrity (hardness, springiness, cohesiveness, gumminess, chewiness and resilience) at day 0 was not significantly different at the end of the storage period experimental egg products $(P>0.05)$. The texture was likely maintained because the factors that influence texture changes ( $\mathrm{pH}$ and water loss) (Croguennec, Nau and Brulé, 2002, Banergee, Keener and Lukito, 2011, Kim, Daeschel and Zho, 2008) remained the same over the 2 week storage time.

There were differences with the "blend" experimental egg $(P<0.05)$ that yielded a poor texture. These samples contained krill oil which is high in phospholipids (Gigliotti, et al., 2011 and Schneider, 2001). High levels of phospholipids can create textural and viscosity changes in food products (Schneider, 2001) and could explain the differences seen in this sample.

\section{Microbial Analysis}

Salmonella spp. or other bacterial contamination was not detected on any day of the 2 week storage time after streaking agar plates with pulverized samples and incubated for 24 hours. 


\section{Sensory Evaluation}

Participants. The 56 panelists were between 18 and 35 years old. Of the participants, $82 \%$ reported consuming eggs at least twice a month. "Cholesterol consumption" was a concern to $86 \%$ of the participants and all participants reported protein consumption being of importance on some level. Only 6 participants reported they would not be likely to purchase a product similar to the experimental eggs.

Attribute testing and ranking. The results of the attribute test showed some significant differences on specific attributes (Table 13). Numerically, the colors of the experimental eggs were more favorably rated than the whole egg; however, this was only statistically significant for the canola oil variation $(P=0.03)$. This is consistent with instrumental measurements that show color of the experimental eggs to have a more yellowish hue and the whole egg to have a greenish hue. This may have influenced panelists color ratings. The color of the whole eggs is due to the high amount of sulfuric compounds in the egg yolk. Ovalbumin is the only protein in the egg white with free sulfhydryl groups (Croguennec, Nau and Brulé, 2002) so the greenish color would not be exhibited in the experimental eggs.

Numerically, the odor, texture between the fingers, and mouthfeel of the whole egg was more favorably rated than the experimental eggs; however these differences were not statistically significant $(P>0.05)$. The differences in types of lipids could explain the differences in odor and texture ratings because fat not only aids in creating texture properties it also carries lipophilic flavors and aromatic compounds (Zuidam and Heinrich, 2010). A lipid encapsulation method could reduce unfavorable odors (Zuidam 
and Heinrich, 2010). No significant difference $(P>0.05)$ was seen in the attributes of flavor, mouthfeel or overall liking. Ranking of the samples supports no significant differences in overall liking because all samples were equally preferred. The average overall liking scores show that all experimental egg variations were generally well liked and $89 \%$ percent of the participants indicated interest in purchasing a product like this.

\section{Conclusions}

The results of the sensory evaluation show that this could be a marketed product if the low scoring attributes (texture between fingers and odor) are corrected. Emulsifier and antioxidant testing to find the best solution to evenly distribute the oils throughout the sample and extend the shelf life could increase the product acceptability. The sensory evaluation was completed less than 24 hours after preparation before the samples had been vacuum packed and problems, such as the occurrence of synersis occur. Sensory evaluations after vacuum packaging and storage time should be conducted. 


\section{References}

Ahn, D. U., Sell, J. L., Jo, C., Chamruspollenrt, M. and Jeffrey, M. (1999). Effect of Dietary Conjugated Linoleic Acid on the Quality Characteristics of Chicken Eggs During Refrigerated Storage. Poultry Science 78(6): 922-928.

Association of Official Analytical Chemists (AOAC). (1995). Official methods of analysis of the association of official analytical chemists, $16^{\text {th }}$ ed. Washington, DC: Assn of Official Analytical Chemists.

Ayadi, M. A., Khemakhem, M., Belgith, H. and Attia, H. (2008). Effect of Moderate Spray Drying Conditions on Functionality of Dried Egg White and Whole Egg. J Food Sci. 73(6):E281-E287.

Banerjee, P., Keener, K. M. and Lukito, V. D. (2011). Influence of carbon dioxide on the activity of chicken egg white lysozyme. Poultry Science 90:889-895.

Bou, Ricard, Codony, Fafael, Tres, Alba, Decker, Eric A. and Guardiola, Francesc. (2009) Dietary Strategies to Improve Nutritional Value, Oxidative Stress and Sensory Properties of Poultry Products. Critical Reviews in Food Science and Nutrition 49:800822.

Bodwell, C. E., Satterlee, L. D., Hackler, L. R. (1980). Protein digestibility of the same protein preparations by human and rat assays and by in vitro enzymatic digestion assays. American Journal of Clinical Nutrition, 33:677-686.

Chen, Y. C., \& Jaczynski, J. (2007a). Gelation of protein recovered from Antarctic krill (Euphausia superba) by isoelectric solublization/precipitation as affected by function additives. Journal of Agricultural and Food Chemistry, 55, 1814-1822.

Chen, Y. C., \& Jaczynski, J. (2007b). Protein recovery from rainbow trout (Oncorhynchus mykiss) processing by-products via isoelectric solubilization / precipitation and its gelation properties as affected by functional additives. Journal of Agricultural and Food Chemistry, 55, 9079-9088.

Cheret, R., Chapleau, N., Delbarre-Ladrat, C., Verrez-Bagnis, V., \& Lamballerie, M. D. (2005). Effects of high pressure on texture and microstructure of sea bass

(Dicentrarchus labrax L.) fillets. Journal of Food Science, 70, E477-483.

Croguennec, T., Nau, F. and Brulé, G. (2002). Influence of pH and Salts on Egg White Gelation. J of Food Sci 67:608-614.

Drewnowski, Adam. (1995). Energy intake and sensory properties of food. American society for Clinical Nutrition, 62s:1081S-1085S. 
Gigliotti, Joseph C., Davenport, Matthew P., Beamer, Sarah K., Tou, Janet C. and Jaczynski, J. (2011) Extraction and Characterisation of Lipids from Antarctic Krill (Euphausia superb). Food Chemistry 125:1028-1036.

Juliano, Pablo, Li, Biansheng, Clark, Stephanie, Mathews, Jason W., Dunne, Patrick C. and Barbosa-Canovas, Gustavo V. (2006a). Descriptive Annalysis of Precooked Egg Products After High-Pressure Processing Combined with Low and High Temperatures. Journal of Food Quality. 29:505-530.

Juliano, Pablo, Toldrà, Monica, Koutchma, Tatiana, Balasubramaniam, V. M., Clark, Stphanie, Mathews, Jason W., Dunne, C. Patrick, Sadler, George and BarbosaCánovas, Gustavo V. (2006b). Texture and Water Retention Improvement in Highpressure Thermally Treated Scrambled Egg Patties. J Food Sci. 71 (2):E52-E61.

Kassis, Nissan, Drake, Sara R., Beamer, Sarah K., Matak, Kristen E. Jaczynski, Jacek. (2010a). Development of nutraceutical egg products with omega-3-rich oils. LWT Food Science and Technology. 43:777-783.

Kassis, Nissan M., Beamer, Sarah K., Matak, Kristen E., Tou, Janet C. and Jaczynski, Jacek. (2010b). Nutritional Composition of Novel Nutraceutical Egg Products Developed with Omega-3-Rich Oils. LWT-Food Science and Technology. 43: 1204-1212.

Ke, P. J., Cervantes, E. and Robles-Martines, C. (1984). Determination of thiobarbituric acid reactive substances (TBARS) in fish tissue by an improved distillation spectrophotometric method. J of the Science of Food Agriculture. 35:1248-1254.

Kim, K. W., Daeschel, M. and Zhao, Y. (2008). Edible Coating for Enhancing Microbial Safety and Extending Shelf Life of Hard-Boiled Eggs. J Food Sci. 73(5):M227-M235.

Kris-Etherton, Penny, M., Harris, Williams S. and Appel, Lawrence J. (2002). Fish Consumption, Fish Oil, Omega-3 Fatty Acids and Cardiovascular Disease. Circulation. 106;2747-2757.

Li, Y., Kloeppel, K. M., Hsieh, F. (1998). Texture of glassy corn cakes as a function of moisture content. J Food Sci. 63:869-872.

Lozano, J. E., Rotstein, E., Urbicain, M. J. (1980). Total porosity and open-pore porosity in the drying of fruits. J Food Sci. 45:1403-1407.

Marshall, A. C., Sams, A. R. and Van Elswyk, M. E. (1994). Oxidative Stability and Sensory Quality of Stored Eggs From Hens Fed 1.5\% Menhaden Oil. J Food Sci. 59:561-563.

McClements, D. J., Decker, E. A. and Weiss, J. (2007). Emulsion-Based Delivery Systems for Lipophilic Bioactive Components. J Food Sci. 72(8):R109-R124. 
National Cancer Institute. (2010). Retrived on February 16, 2011 from the National Cancer Institute website: http://riskfactor.cancer.gov/diet/foodsources/.

Reppond, K. D. and Babbitt, J. K. (1997) Gel Properties of Surimi from Various Fish Species as Affected by Moisture Content. J Food Sci. 62(1):33-36.

Scheideler, S. E., Froning, G., Cuppett, S. (1997). Studies of Consumer Acceptance of High Omega-3 Fatty Acid-Enriced Eggs. J. Appl. Poultry Res. 6:137-146.

Schneider, Michael (2001). Phospholipids for Functional Food. Eur. J. Lipid Sci. Technol. 103:98-101.

Simopoulos, A. P. (2006). Evolutionary aspects of diet, the omega-6/omega-3 ratio and genetic variation: nutritional implications for chronic diseases. Biomedicine and Pharmacotherapy, 60, 502-507.

Taskaya, L., Chen, Y. C., \& Jaczynski, J. (2009a). Color improvement by titanium dioxide and its effect on gelation and texture of proteins recovered from whole fish using isoelectric solubilization / precipitation. LWT - Food Science and Technology. Revision submitted.

Taskaya, L., Chen, Y. C., \& Jaczynski, J. (2009b). Functional properties of proteins recovered from whole gutted silver carp (Hypophthalmichthys molitrix) by isoelectric solubilization / precipitation. LWT - Food Science and Technology 42(6), 1082-1089.

Taskaya, L., Chen, Y. C., Beamer, S., \& Jaczynski J. (2009c). Texture and colour properties of proteins recovered from whole gutted silver carp (Hypophthalmichthys molitrix) using isoelectric solubilisation / precipitation. Journal of the Science of Food and Agriculture 89(2), 349-358.

Tinkler, Charles Kenneth and Soar, Marion Crossland. (1920). The formation of ferrous sulphide in eggs during cooking. Chemical Laboratory, Household and Social Science Dept, King's College for Women. 114-119.

USDA Food Composition (2010). Accessed on January 25, 2011.

http://www.nal.usda.gov/fnic/foodcomp/cgi-bin/list_nut_edit.pl

Van Elswyk, Mary E. (1997). Comparison of n-3 Fatty acid Sources in Laying Hen Rations for Improvement of Whole Egg Nutritional Quality: a Review. British J. of Nutr. 78:S61-S69.

Yu Tc, Sinnhuber RO. (1957). 2-Thiobarbituric acid method for the measurement of racidity in fisher products. Food Technology 11:104-108. 
Zuidam, Nicolaas Jan and Heinrich, Emmanuel. Encapsulation Technologies for Active Food Ingredients and Food Processing. (Chapter 5) (2010). Vlaardingen, The Netherlands. Unilever R\&D Vlaardinger, Olivier van Noortlaan. 
Table 1: $\mathrm{pH}$ of cooked whole egg and experimental eggs with addition of canola, flaxseed, menhanden, DHAS (algae) and a blend of DHAS, flaxseed and krill oils over a two-week storage period with no significant differences in each sample over storage time.

$\begin{array}{lllllll}\text { Treatment } & \text { Day } 0 & \text { Day } 2 & \text { Day } 4 & \text { Day } 6 & \text { Day } 8 & \text { Day } 14\end{array}$

$\begin{array}{ccccccc}\text { Whole Egg } & 8.0 \pm 0.1 \mathrm{~B} & 8.1 \pm 0.2 \mathrm{~B} & 8.1 \pm 0.2 \mathrm{~B} & 8.1 \pm 0.1 \mathrm{~B} & 8.0 \pm 0.2 \mathrm{C} & 8.2 \pm 0.3 \mathrm{~B} \\ \text { Canola } & 8.5 \pm 0.1 \mathrm{~A} & 8.6 \pm 0.1 \mathrm{~A} & 8.6 \pm 0.1 \mathrm{~A} & 8.6 \pm 0.1 \mathrm{~A} & 8.6 \pm 0.2 \mathrm{~A} & 8.7 \pm 0.2 \mathrm{~A} \\ & & & & & & \\ \text { Flax } & 8.6 \pm 0.1 \mathrm{~A} & 8.6 \pm 0.1 \mathrm{~A} & 8.6 \pm 0.2 \mathrm{~A} & 8.7 \pm 0.1 \mathrm{~A} & 8.6 \pm 0.2 \mathrm{~A} & 8.7 \pm 0.2 \mathrm{~A}\end{array}$

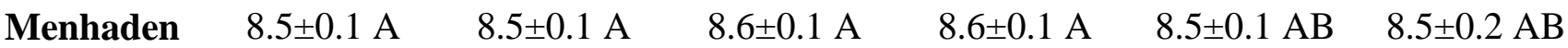
$\begin{array}{ccccccc}\text { DHAS } & 8.4 \pm 0.2 \mathrm{~A} & 8.5 \pm 0.1 \mathrm{~A} & 8.5 \pm 0.1 \mathrm{~A} & 8.5 \pm 0.2 \mathrm{~A} & 8.4 \pm 0.2 \mathrm{~B} & 8.5 \pm 0.3 \mathrm{AB}\end{array}$
Blend
$8.4 \pm 0.2 \mathrm{~A}$
$8.5 \pm 0.1 \mathrm{~A}$
$8.5 \pm 0.1 \mathrm{~A}$
$8.5 \pm 0.1 \mathrm{~A}$
$8.5 \pm 0.1 \mathrm{AB} \quad 8.5 \pm 0.2 \mathrm{AB}$

Different letters within the same column indicate significant differences (Tukey HSD mean pair comparison, $\mathrm{P}<0.05)$. Data expressed as mean value \pm standard deviation. 
Table 2: Lightness color values $(L)$ of cooked whole egg and experimental eggs with addition of canola, flaxseed, menhanden, DHAS (algae) and a blend of DHAS, flaxseed and krill oils over a two-week storage period with no differences in each sample over time.

$\begin{array}{lllllll}\text { Treatment } & \text { Day } 0 & \text { Day } 2 & \text { Day } 4 & \text { Day } 6 & \text { Day } 8 & \text { Day } 14\end{array}$

$\begin{array}{lllllll}\text { Whole Egg } \quad 84.1 \pm 2.9 \mathrm{~A} & 82.4 \pm 3.8 \mathrm{~A} & 82.8 \pm 3.3 \mathrm{~A} & 82.0 \pm 5.1 \mathrm{~A} & 81.6 \pm 3.7 \mathrm{~A} & 83.4 \pm 4.1 \mathrm{~A}\end{array}$

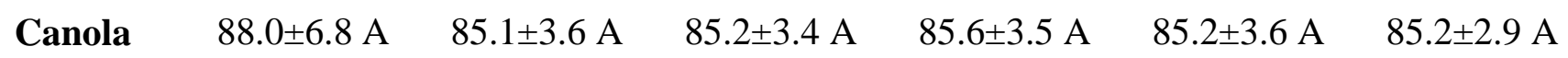

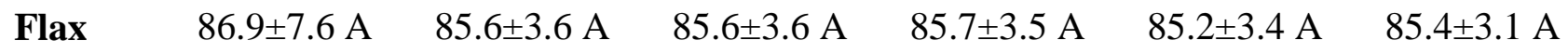

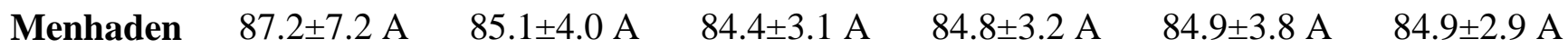

$\begin{array}{lllllll}\text { DHAS } & 88.8 \pm 6.4 \mathrm{~A} & 86.2 \pm 3.4 \mathrm{~A} & 86.4 \pm 3.4 \mathrm{~A} & 86.6 \pm 3.8 \mathrm{~A} & 86.6 \pm 4.0 \mathrm{~A} & 86.6 \pm 3.7 \mathrm{~A}\end{array}$

Blend $\quad 73.7 \pm 4.4 \mathrm{~B} \quad 73.5 \pm 4.1 \mathrm{~B} \quad 72.6 \pm 1.9 \mathrm{~B} \quad 74.1 \pm 3.8 \mathrm{~B} \quad 74.2 \pm 3.3 \mathrm{~B} \quad 73.4 \pm 4.1 \mathrm{~B}$

Different letters within the same column indicate significant differences (Tukey-Kramer mean pair comparison, $\mathrm{P}<0.05)$. Data expressed as mean value \pm standard deviation. 
Table 3: $\mathrm{a}^{*}$ color values (positive value $=$ reddish hue, negative value $=$ greenish hue) of cooked whole egg and experimental eggs with addition of canola, flaxseed, menhanden, DHAS (algae) and a blend of DHAS, flaxseed and krill oils over a twoweek storage period with no differences in each sample over time.

$\begin{array}{lllllll}\text { Treatment } & \text { Day } 0 & \text { Day } 2 & \text { Day } 4 & \text { Day } 6 & \text { Day } 8 & \text { Day } 14\end{array}$

\begin{tabular}{|c|c|c|c|c|c|c|}
\hline Whole Egg & $-4.4 \pm 1.0 \mathrm{C}$ & $-5.0 \pm 0.6 \mathrm{C}$ & $-4.7 \pm 0.6 \mathrm{C}$ & $5.3 \pm 0.9 \mathrm{C}$ & $-4.8 \pm 1.2 \mathrm{C}$ & $-5.2 \pm 1.0 \mathrm{C}$ \\
\hline Canola & $5.8 \pm 3.9 \mathrm{~B}$ & $5.7 \pm 4.2 \mathrm{~B}$ & $6.1 \pm 4.6 \mathrm{~B}$ & $5.4 \pm 4.3 \mathrm{~B}$ & $5.7 \pm 4.4 \mathrm{~B}$ & $5.0 \pm 4.5 \mathrm{~B}$ \\
\hline Flax & $5.2 \pm 3.5 \mathrm{~B}$ & $4.8 \pm 3.9 \mathrm{~B}$ & $5.2 \pm 4.4 \mathrm{~B}$ & $4.6 \pm 4.0 \mathrm{~B}$ & $4.8 \pm 4.0 \mathrm{~B}$ & $4.5 \pm 3.8 \mathrm{~B}$ \\
\hline Menhaden & $6.3 \pm 4.1 \mathrm{~B}$ & $5.8 \pm 4.6 \mathrm{~B}$ & $6.6 \pm 4.8 \mathrm{~B}$ & $5.6 \pm 4.1 \mathrm{~B}$ & $5.8 \pm 4.7 \mathrm{~B}$ & $5.8 \pm 4.2 \mathrm{~B}$ \\
\hline $\begin{array}{c}\text { DHAS } \\
\text { (Algae) }\end{array}$ & $3.7 \pm 4.3 \mathrm{~B}$ & $3.2 \pm 4.4 \mathrm{~B}$ & $3.6 \pm 4.2 \mathrm{~B}$ & $3.1 \pm 4.7 \mathrm{~B}$ & $3.4 \pm 4.5 \mathrm{~B}$ & $2.9 \pm 4.6 \mathrm{~B}$ \\
\hline Blend & $23.3 \pm 1.8 \mathrm{~A}$ & $21.1 \pm 3.8 \mathrm{~A}$ & $22.7 \pm 2.0 \mathrm{~A}$ & $20.4 \pm 3.4 \mathrm{~A}$ & $20.5 \pm 2.6 \mathrm{~A}$ & $20.3 \pm 4.1 \mathrm{~A}$ \\
\hline
\end{tabular}


Table 4: $b^{*}$ color values (positive value = yellowish, negative value $=$ bluish hue) of cooked whole egg and experimental eggs with addition of canola, flaxseed, menhanden, DHAS (algae) and a blend of DHAS, flaxseed and krill oils over a twoweek storage period with no differences in each sample over time.

$\begin{array}{lllllll}\text { Treatment } & \text { Day } 0 & \text { Day } 2 & \text { Day } 4 & \text { Day } 6 & \text { Day } 8 & \text { Day } 14\end{array}$

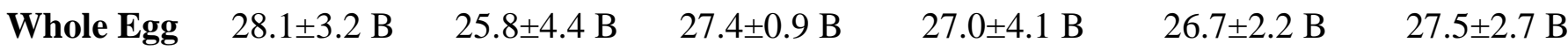

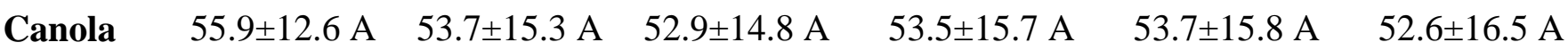

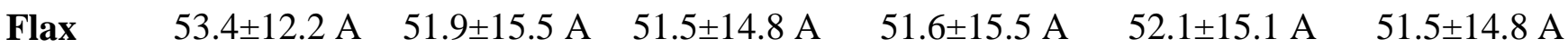

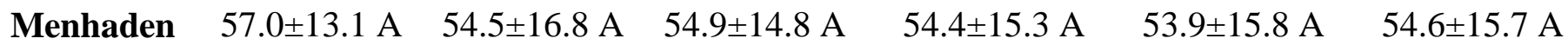

$\begin{array}{lllllll}\text { DHAS } & 48.0 \pm 14.8 \text { A } & 45.5 \pm 16.3 \text { A } & 45.8 \pm 15.5 \text { A } & 45.2 \pm 16.4 \text { AB } & 46.3 \pm 15.8 \text { A } & 45.1 \pm 16.3 \mathrm{AB}\end{array}$

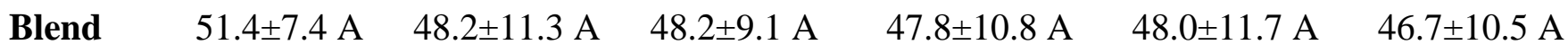

Different letters within the same column indicate significant differences (Tukey-Kramer mean pair comparison, $\mathrm{P}<0.05)$. Data expressed as mean value \pm standard deviation. 
Table 5: Syneresis expressed as percent weight loss of cooked whole egg and experimental eggs with addition of canola, flaxseed, menhanden, DHAS (algae) and a blend of DHAS, flaxseed and krill oils over a two-week storage period.

$\begin{array}{llllll}\text { Treatment } & \text { Day } 2 & \text { Day } 4 & \text { Day } 6 & \text { Day } 8 & \text { Day } 14\end{array}$

Whole Egg $\quad 6.0 \pm 1.0 \mathrm{C}, \mathrm{ab} \quad 5.7 \pm 1.5 \mathrm{~B}, \mathrm{~b} \quad 6.7 \pm 0.6 \mathrm{~A}, \mathrm{ab} \quad 7.0 \pm 0.0 \mathrm{~B}, \mathrm{ab} \quad 8.0 \pm 0.0 \mathrm{~B}, \mathrm{a}$

Canola $\quad 13.0 \pm 2.0 \mathrm{~A}$, a $\quad 12.3 \pm 0.6 \mathrm{~A}, \mathrm{a} \quad 13.0 \pm 1.0 \mathrm{~A}$, a $\quad 12.3 \pm 0.6 \mathrm{~A}$, a $\quad 12.7 \pm 1.5 \mathrm{~A}, \mathrm{a}$

Flax $\quad 10.3 \pm 0.6 \mathrm{AB}, \mathrm{a} \quad 10.0 \pm 1.0 \mathrm{~A}, \mathrm{a} \quad 8.3 \pm 5.5 \mathrm{~A}, \mathrm{a} \quad 12.7 \pm 2.9 \mathrm{~A}, \mathrm{a} \quad 11.0 \pm 1.0 \mathrm{~A}, \mathrm{a}$

Menhaden $\quad 11.7 \pm 1.2 \mathrm{AB}$, a $\quad 11.3 \pm 1.5 \mathrm{~A}, \mathrm{a} \quad 10.3 \pm 1.5 \mathrm{~A}, \mathrm{a} \quad 11.3 \pm 0.6 \mathrm{~A}, \mathrm{a} \quad 12.0 \pm 0.0 \mathrm{~A}, \mathrm{a}$

$\begin{gathered}\text { DHAS } \\ \text { (Algae) }\end{gathered} \quad 10.3 \pm 0.6 \mathrm{AB}$, a $\quad 10.3 \pm 1.5 \mathrm{~A}$, a $\quad 11.3 \pm 1.5 \mathrm{~A}, \mathrm{a} \quad 11.3 \pm 1.2 \mathrm{~A}, \mathrm{a} \quad 11.7 \pm 1.5 \mathrm{~A}, \mathrm{a}$

Blend $\quad 9.3 \pm 0.6 \mathrm{~B}, \mathrm{a} \quad 9.3 \pm 1.5 \mathrm{~A}, \mathrm{a} \quad 8.6 \pm 1.5 \mathrm{~A}, \mathrm{a} \quad 11.0 \pm 1.7 \mathrm{AB}, \mathrm{a} \quad 11.3 \pm 1.2 \mathrm{~A}, \mathrm{a}$

Different capital letters within the same column indicate significant differences. Different lowercase letters within the same row indicate significant differences. (Tukey-Kramer mean pair comparison, $\mathrm{P}<0.05)$. Data expressed as mean value \pm standard deviation. 
Table 6: $\mathrm{mg}$ MDA/kg sample in cooked whole egg and experimental eggs with addition of canola, flaxseed, menhanden, DHAS (algae) and a blend of DHAS, flaxseed and krill oils over a two-week storage period.

\begin{tabular}{|c|c|c|c|c|c|c|}
\hline Treatment & Day 0 & Day 2 & Day 4 & Day 6 & Day 8 & Day 14 \\
\hline Whole Egg & $1.5 \pm 0.2 \mathrm{BC}, \mathrm{b}$ & $4.6 \pm 0.2 \mathrm{~A}, \mathrm{a}$ & $1.6 \pm 0.3 \mathrm{AB}, \mathrm{b}$ & $1.6 \pm 0.7 \mathrm{BC}, \mathrm{b}$ & $1.6 \pm 0.1 \mathrm{~B}, \mathrm{~b}$ & $2.7 \pm 1.4 \mathrm{~A}, \mathrm{~b}$ \\
\hline Canola & $2.2 \pm 0.2 \mathrm{AB}, \mathrm{bc}$ & $3.0 \pm 0.6 \mathrm{~B}, \mathrm{ab}$ & $1.6 \pm 0.7 \mathrm{AB}, \mathrm{bcd}$ & $0.7 \pm 0.3 \mathrm{C}, \mathrm{d}$ & $1.5 \pm 0.7 \mathrm{~B}, \mathrm{~cd}$ & $3.6 \pm 1.0 \mathrm{~A}, \mathrm{a}$ \\
\hline Flax & $2.5 \pm 0.6 \mathrm{~A}, \mathrm{a}$ & $3.0 \pm 0.8 \mathrm{AB}, \mathrm{a}$ & $2.7 \pm 0.7 \mathrm{~A}, \mathrm{a}$ & $2.6 \pm 0.7 \mathrm{AB}, \mathrm{a}$ & $2.1 \pm 0.4 \mathrm{~B}, \mathrm{a}$ & $1.9 \pm 0.6 \mathrm{~A}, \mathrm{a}$ \\
\hline Menhaden & $1.6 \pm 0.2 \mathrm{BC}, \mathrm{a}$ & $2.6 \pm 0.1 \mathrm{~B}, \mathrm{a}$ & $1.0 \pm 0.2 \mathrm{~B}, \mathrm{a}$ & $2.8 \pm 0.7 \mathrm{~A}, \mathrm{a}$ & $3.5 \pm 2.0 \mathrm{AB}, \mathrm{a}$ & $2.5 \pm 1.3 \mathrm{~A}, \mathrm{a}$ \\
\hline DHAS (Algae) & $3.0 \pm 0.4 \mathrm{~A}, \mathrm{a}$ & $2.3 \pm 0.8 \mathrm{~B}, \mathrm{ab}$ & $2.0 \pm 0.2 \mathrm{AB}, \mathrm{ab}$ & $2.7 \pm 0.7 \mathrm{~A}, \mathrm{a}$ & $1.8 \pm 0.7 \mathrm{~B}, \mathrm{ab}$ & $1.3 \pm 0.2 \mathrm{~A}, \mathrm{~b}$ \\
\hline Blend & $1.3 \pm 0.1 \mathrm{C}, \mathrm{c}$ & $3.5 \pm 0.0 \mathrm{AB}, \mathrm{b}$ & $2.8 \pm 0.1 \mathrm{~A}, \mathrm{bc}$ & $3.2 \pm 1.0 \mathrm{~A}, \mathrm{~b}$ & $6.0 \pm 0.7 \mathrm{~A}, \mathrm{a}$ & $1.4 \pm 0.4 \mathrm{~A}, \mathrm{c}$ \\
\hline
\end{tabular}

Different capital letters within the same column indicate significant differences. Different lowercase letters within the same row indicate significant differences. (Tukey-Kramer mean pair comparison, $P<0.05$ ). Data expressed as mean value \pm standard deviation. 
Table 7: Springiness of cooked whole egg and experimental eggs with addition of canola, flaxseed, menhanden, DHAS (algae) and a blend of DHAS, flaxseed and krill oils over a two-week storage period.

\begin{tabular}{|c|c|c|c|c|c|c|}
\hline Treatment & Day 0 & Day 2 & Day 4 & Day 6 & Day 8 & Day 14 \\
\hline Whole Egg & $2.0 \pm 0.0 \mathrm{~A}, \mathrm{a}$ & $2.0 \pm 0.0 \mathrm{~A}, \mathrm{a}$ & $2.0 \pm 0.1 \mathrm{~A}, \mathrm{a}$ & $2.0 \pm 0.0 \mathrm{AB}, \mathrm{a}$ & $2.0 \pm 0.1 \mathrm{AB}, \mathrm{a}$ & $2.0 \pm 0.0 \mathrm{~A}, \mathrm{a}$ \\
\hline Canola & $1.5 \pm 0.3 \mathrm{~A}, \mathrm{a}$ & $1.4 \pm 0.4 \mathrm{~B}, \mathrm{a}$ & $1.6 \pm 0.3 \mathrm{~A}, \mathrm{a}$ & $1.6 \pm 0.3 \mathrm{~B}, \mathrm{a}$ & $1.6 \pm 0.3 \mathrm{~B}, \mathrm{a}$ & $1.8 \pm 0.4 \mathrm{~A}, \mathrm{a}$ \\
\hline Flax & $1.9 \pm 0.3 \mathrm{~A}, \mathrm{a}$ & $1.6 \pm 0.4 \mathrm{AB}, \mathrm{a}$ & $1.7 \pm 0.4 \mathrm{~A}, \mathrm{a}$ & $1.7 \pm 0.6 \mathrm{AB}, \mathrm{a}$ & $1.8 \pm 0.2 \mathrm{AB}, \mathrm{a}$ & $1.7 \pm 0.5 \mathrm{~A}, \mathrm{a}$ \\
\hline Menhaden & $1.4 \pm 0.3 \mathrm{~A}, \mathrm{a}$ & $1.6 \pm 0.5 \mathrm{AB}, \mathrm{a}$ & $1.7 \pm 1.0 \mathrm{~A}, \mathrm{a}$ & $1.9 \pm 0.2 \mathrm{AB}, \mathrm{a}$ & $1.7 \pm 0.4 \mathrm{AB}, \mathrm{a}$ & $2.0 \pm 0.2 \mathrm{~A}, \mathrm{a}$ \\
\hline $\begin{array}{l}\text { DHAS } \\
\text { (Algae) }\end{array}$ & $1.8 \pm 0.6 \mathrm{~A}, \mathrm{a}$ & $1.9 \pm 0.2 \mathrm{AB}, \mathrm{a}$ & $2.0 \pm 0.1 \mathrm{~A}, \mathrm{a}$ & $1.9 \pm 0.4 \mathrm{AB}, \mathrm{a}$ & $2.0 \pm 0.2 \mathrm{~A}, \mathrm{a}$ & $1.9 \pm 0.2 \mathrm{~A}, \mathrm{a}$ \\
\hline Blend & $1.6 \pm 0.4 \mathrm{~A}, \mathrm{~b}$ & $1.9 \pm 0.4 \mathrm{AB}, \mathrm{ab}$ & $2.1 \pm 0.2 \mathrm{~A}, \mathrm{ab}$ & $2.1 \pm 0.3 \mathrm{~A}, \mathrm{a}$ & $1.9 \pm 0.2 \mathrm{AB}, \mathrm{ab}$ & $2.0 \pm 0.4 \mathrm{~A}, \mathrm{ab}$ \\
\hline
\end{tabular}

Different capital letters within the same column indicate significant differences. Different lowercase letters within the same row indicate significant differences. (Tukey-Kramer mean pair comparison, $\mathrm{P}<0.05$ ). Data expressed as mean value \pm standard deviation. 
Table 8: Gumminess of cooked whole egg and experimental eggs with addition of canola, flaxseed, menhanden, DHAS (algae) and a blend of DHAS, flaxseed and krill oils over a two-week storage period with no significant differences in each sample over storage time.

\begin{tabular}{|c|c|c|c|c|c|c|}
\hline Treatment & Day 0 & Day 2 & Day 4 & Day 6 & Day 8 & Day 14 \\
\hline Whole Egg & $948.6 \pm 209.2 \mathrm{~A}$ & $1041.4 \pm 210.8 \mathrm{~A}$ & $713.3 \pm 523.9 \mathrm{~A}$ & $1010.1 \pm 194.7 \mathrm{~A}$ & $1010.32 \pm 173.8 \mathrm{~A}$ & $1079.5 \pm 219.0 \mathrm{~A}$ \\
\hline Canola & $629.4 \pm 249.0 \mathrm{AB}$ & $769.9 \pm 147.4 \mathrm{AB}$ & $678.3 \pm 291.8 \mathrm{AB}$ & $501.8 \pm 299.7 \mathrm{ABC}$ & $638.2 \pm 375.4 \mathrm{AB}$ & $710.1 \pm 364.0 \mathrm{~A}$ \\
\hline Flax & $776.8 \pm 508.6 \mathrm{~A}$ & $878.7 \pm 381.0 \mathrm{AB}$ & $718.8 \pm 415.0 \mathrm{~A}$ & $537.8 \pm 454.9 \mathrm{ABC}$ & $657.0 \pm 536.4 \mathrm{~A}$ & $701.1 \pm 439.3 \mathrm{~A}$ \\
\hline Menhaden & $900.5 \pm 157.6 \mathrm{~A}$ & $593.3 \pm 310.1 \mathrm{BC}$ & $828.6 \pm 434.4 \mathrm{~A}$ & $690.5 \pm 406.4 \mathrm{AB}$ & $973.0 \pm 237.1 \mathrm{~A}$ & $644.3 \pm 475.7 \mathrm{~A}$ \\
\hline $\begin{array}{c}\text { DHAS } \\
\text { (Algae) }\end{array}$ & $501.5 \pm 415.1 \mathrm{AB}$ & $626.3 \pm 407.1 \mathrm{AB}$ & 719.1土419.6 A & $480.3 \pm 307.6 \mathrm{BC}$ & $580.0 \pm 431.9 \mathrm{AB}$ & $756.4 \pm 338.2 \mathrm{~A}$ \\
\hline Blend & $195.3 \pm 67.9 \mathrm{~B}$ & $207.1 \pm 116.1 \mathrm{C}$ & $107.4 \pm 48.8 \mathrm{~B}$ & $137.0 \pm 74.4 \mathrm{C}$ & $161.0 \pm 76.9 \mathrm{~B}$ & $147.4 \pm 124.8 \mathrm{~B}$ \\
\hline
\end{tabular}

Different letters within the same column indicate significant differences (Tukey-Kramer mean pair comparison, $\mathrm{P}<0.05)$.

Data expressed as mean value \pm standard deviation. 
Table 9: Cohesiveness of cooked whole egg and experimental eggs with addition of canola, flaxseed, menhanden, DHAS (algae) and a blend of DHAS, flaxseed and krill oils over a two-week storage period.

\begin{tabular}{ccccccc} 
Treatment & Day 0 & Day 2 & Day 4 & Day 6 & Day 8 & Day 14 \\
\hline Whole Egg & $0.6 \pm 0.1 \mathrm{~A}, \mathrm{ab}$ & $0.6 \pm 0.1 \mathrm{~A}, \mathrm{ab}$ & $0.5 \pm 0.2 \mathrm{~A}, \mathrm{~b}$ & $0.6 \pm 0.1 \mathrm{~A}, \mathrm{ab}$ & $0.6 \pm 0.0 \mathrm{~A}, \mathrm{ab}$ & $0.6 \pm 0.0 \mathrm{~A}, \mathrm{a}$ \\
Canola & $0.6 \pm 0.1 \mathrm{~A}, \mathrm{a}$ & $0.6 \pm 0.0 \mathrm{~A}, \mathrm{a}$ & $0.6 \pm 0.1 \mathrm{~A}, \mathrm{a}$ & $0.5 \pm 0.1 \mathrm{~A}, \mathrm{a}$ & $0.5 \pm 0.1 \mathrm{~A}, \mathrm{a}$ & $0.6 \pm 0.1 \mathrm{~A}, \mathrm{a}$ \\
& & & & & & \\
Flax & $0.5 \pm 0.2 \mathrm{AB}, \mathrm{a}$ & $0.6 \pm 0.1 \mathrm{~A}, \mathrm{a}$ & $0.6 \pm 0.1 \mathrm{~A}, \mathrm{a}$ & $0.5 \pm 0.2 \mathrm{AB}, \mathrm{a}$ & $0.5 \pm 0.2 \mathrm{~A}, \mathrm{a}$ & $0.5 \pm 0.1 \mathrm{~A}, \mathrm{a}$ \\
Menhaden & $0.6 \pm 0.0 \mathrm{~A}, \mathrm{a}$ & $0.5 \pm 0.1 \mathrm{AB}, \mathrm{a}$ & $0.6 \pm 0.2 \mathrm{~A}, \mathrm{a}$ & $0.5 \pm 0.2 \mathrm{~A}, \mathrm{a}$ & $0.6 \pm 0.0 \mathrm{~A}, \mathrm{a}$ & $0.5 \pm 0.2 \mathrm{~A}, \mathrm{a}$ \\
$\begin{array}{c}\text { DHAS } \\
\text { (Algae) }\end{array}$ & $0.5 \pm 0.2 \mathrm{AB}, \mathrm{a}$ & $0.5 \pm 0.1 \mathrm{AB}, \mathrm{a}$ & $0.5 \pm 0.1 \mathrm{~A}, \mathrm{a}$ & $0.5 \pm 0.1 \mathrm{AB}, \mathrm{a}$ & $0.5 \pm 0.1 \mathrm{~A}, \mathrm{a}$ & $0.6 \pm 0.1 \mathrm{~A}, \mathrm{a}$ \\
Blend & $0.4 \pm 0.1 \mathrm{~B}, \mathrm{a}$ & $0.4 \pm 0.1 \mathrm{~B}, \mathrm{a}$ & $0.3 \pm 0.1 \mathrm{~B}, \mathrm{a}$ & $0.3 \pm 0.1 \mathrm{~B}, \mathrm{a}$ & $0.3 \pm 0.1 \mathrm{~B}, \mathrm{a}$ & $0.3 \pm 0.1 \mathrm{~B}, \mathrm{a}$
\end{tabular}

Different capital letters within the same column indicate significant differences. Different lowercase letters within the same row indicate significant differences. (Tukey-Kramer mean pair comparison, $\mathrm{P}<0.05$ ). Data expressed as mean value \pm standard deviation. 
Table 10: Chewiness of cooked whole egg and experimental eggs with addition of canola, flaxseed, menhanden, DHAS (algae) and a blend of DHAS, flaxseed and krill oils over a two-week storage period with no significant differences in each sample over storage time.

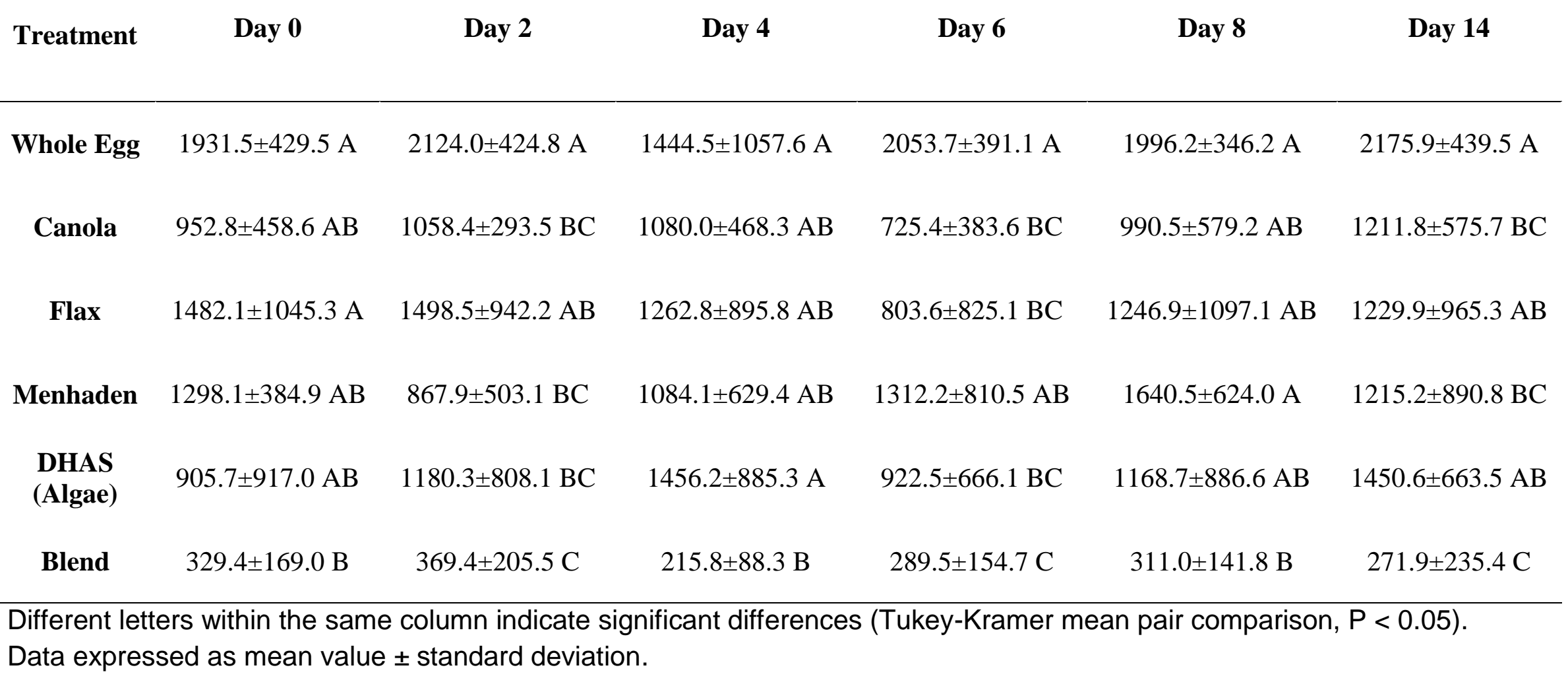


Table 11: Resilience of cooked whole egg and experimental eggs with addition of canola, flaxseed, menhanden, DHAS (algae) and a blend of DHAS, flaxseed and krill oils over a two-week storage period with no significant differences in each sample over storage time.

$\begin{array}{lllllll}\text { Treatment } & \text { Day } 0 & \text { Day } 2 & \text { Day } 4 & \text { Day } 6 & \text { Day } 8 & \text { Day } 14\end{array}$

\begin{tabular}{|c|c|c|c|c|c|c|}
\hline Whole Egg & $0.3 \pm 0.0 \mathrm{AB}$ & $0.3 \pm 0.0 \mathrm{~B}$ & $0.3 \pm 0.0 \mathrm{~B}$ & $0.3 \pm 0.0 \mathrm{~B}$ & $0.3 \pm 0.0 \mathrm{~B}$ & $0.3 \pm 0.0 \mathrm{~B}$ \\
\hline Canola & $0.3 \pm 0.0 \mathrm{~B}$ & $0.3 \pm 0.0 \mathrm{~B}$ & $0.3 \pm 0.0 \mathrm{~B}$ & $0.3 \pm 0.0 \mathrm{~B}$ & $0.3 \pm 0.0 \mathrm{~B}$ & $0.3 \pm 0.0 \mathrm{~B}$ \\
\hline Flax & $0.4 \pm 0.1 \mathrm{AB}$ & $0.3 \pm 0.0 \mathrm{~B}$ & $0.3 \pm 0.0 \mathrm{~B}$ & $0.3 \pm 0.1 \mathrm{~B}$ & $0.3 \pm 0.1 \mathrm{~B}$ & $0.3 \pm 0.0 \mathrm{~B}$ \\
\hline Menhaden & $0.3 \pm 0.0 \mathrm{AB}$ & $0.3 \pm 0.0 \mathrm{~B}$ & $0.3 \pm 0.0 \mathrm{~B}$ & $0.3 \pm 0.0 \mathrm{~B}$ & $0.3 \pm 0.0 \mathrm{~B}$ & $0.3 \pm 0.1 \mathrm{~B}$ \\
\hline $\begin{array}{l}\text { DHAS } \\
\text { (Algae) }\end{array}$ & $0.3 \pm 0.0 \mathrm{AB}$ & $0.3 \pm 0.1 \mathrm{~B}$ & $0.4 \pm 0.1 \mathrm{~B}$ & $0.3 \pm 0.1 \mathrm{~B}$ & $0.3 \pm 0.0 \mathrm{~B}$ & $0.3 \pm 0.0 \mathrm{~B}$ \\
\hline Blend & $0.4 \pm 0.1 \mathrm{~A}$ & $0.4 \pm 0.1 \mathrm{~A}$ & $0.5 \pm 0.2 \mathrm{~A}$ & $0.5 \pm 0.1 \mathrm{~A}$ & $0.4 \pm 0.1 \mathrm{~A}$ & $0.5 \pm 0.2 \mathrm{~A}$ \\
\hline
\end{tabular}


Table 12: Hardness of cooked whole egg and experimental eggs with addition of canola, flaxseed, menhanden, DHAS (algae) and a blend of DHAS, flaxseed and krill oils over a two-week storage period with no significant differences in each sample over storage time.

\begin{tabular}{|c|c|c|c|c|c|c|}
\hline Treatment & Day 0 & Day 2 & Day 4 & Day 6 & Day 8 & Day 14 \\
\hline Whole Egg & $1521.4 \pm 257.5 \mathrm{~A}$ & $1627.4 \pm 254.7 \mathrm{~A}$ & $1183.4 \pm 712.4 \mathrm{~A}$ & $1613.6 \pm 189.8 \mathrm{~A}$ & $1589.5 \pm 213.3 \mathrm{~A}$ & $1650.8 \pm 247.9 \mathrm{~A}$ \\
\hline Canola & $1083.5 \pm 321.2 \mathrm{AB}$ & $1241.2 \pm 186.7 \mathrm{~A}$ & $1160.5 \pm 359.6 \mathrm{~A}$ & $913.8 \pm 435.8 \mathrm{AB}$ & $1066.0 \pm 492.2 \mathrm{AB}$ & $1157.6 \pm 501.9 \mathrm{~A}$ \\
\hline Flax & $1250.5 \pm 701.0 \mathrm{~A}$ & $1418.0 \pm 491.8 \mathrm{~A}$ & $1160.3 \pm 571.4 \mathrm{~A}$ & $953.7 \pm 645.7 \mathrm{AB}$ & $1116.8 \pm 712.8 \mathrm{AB}$ & $1182.5 \pm 599.7 \mathrm{~A}$ \\
\hline Menhaden & $1421.3 \pm 218.5 \mathrm{~A}$ & $1105.4 \pm 436.9 \mathrm{~A}$ & $1318.3 \pm 584.1 \mathrm{~A}$ & $1155.3 \pm 530.9 \mathrm{~A}$ & $1535.3 \pm 298.1 \mathrm{~A}$ & $1093.8 \pm 659.5 \mathrm{~A}$ \\
\hline DHAS (Algae) & $921.3 \pm 575.0 \mathrm{AB}$ & $1114.0 \pm 550.8 \mathrm{~A}$ & $1222.2 \pm 558.7 \mathrm{~A}$ & $921.2 \pm 425.8 \mathrm{AB}$ & $1002.5 \pm 575.9 \mathrm{AB}$ & $1293.2 \pm 402.3 \mathrm{~A}$ \\
\hline Blend & $503.8 \pm 110.2 \mathrm{~B}$ & $504.0 \pm 203.2 \mathrm{~B}$ & $375.3 \pm 117.3 \mathrm{~B}$ & $404.0 \pm 180.0 \mathrm{~B}$ & $487.3 \pm 172.4 \mathrm{~B}$ & $428.7 \pm 241.1 \mathrm{~B}$ \\
\hline
\end{tabular}


Table 13: Sensory attribute evaluation and ranking of cooked whole egg and experimental eggs with addition of canola, flaxseed, DHAS (algae).

\begin{tabular}{|c|c|c|c|c|c|c|c|}
\hline Treatment & Color & Odor & Flavor & $\begin{array}{l}\text { Texture } \\
\text { Between } \\
\text { Fingers }\end{array}$ & Mouthfeel & $\begin{array}{c}\text { Overall } \\
\text { Liking }\end{array}$ & Ranking \\
\hline Whole Egg & $5.7 \pm 2.2 \mathrm{~B}$ & $5.6 \pm 2.0 \mathrm{~A}$ & $6.1 \pm 2.2 \mathrm{~A}$ & $6.3 \pm 1.7 \mathrm{~A}$ & $6.5 \pm 1.9 \mathrm{~A}$ & $5.9 \pm 2.0 \mathrm{~A}$ & $2.4 \pm 1.2 \mathrm{~A}$ \\
\hline Canola & $6.7 \pm 1.6 \mathrm{~A}$ & $5.3 \pm 2.0 \mathrm{AB}$ & $6.2 \pm 1.9 \mathrm{~A}$ & $4.9 \pm 1.8 \mathrm{~B}$ & $6.0 \pm 1.7 \mathrm{~A}$ & $6.0 \pm 1.8 \mathrm{~A}$ & $2.4 \pm 1.1 \mathrm{~A}$ \\
\hline Flax & $6.6 \pm 1.6 \mathrm{AB}$ & $4.5 \pm 2.1 \mathrm{~B}$ & $5.3 \pm 2.0 \mathrm{~A}$ & $5.5 \pm 1.7 \mathrm{AB}$ & $5.7 \pm 2.1 \mathrm{~A}$ & $5.7 \pm 1.8 \mathrm{~A}$ & $2.4 \pm 1.1 \mathrm{~A}$ \\
\hline $\begin{array}{c}\text { DHAS } \\
\text { (Algae) }\end{array}$ & $5.9 \pm 1.9 \mathrm{AB}$ & $4.9 \pm 2.2 \mathrm{AB}$ & $6.0 \pm 2.1 \mathrm{~A}$ & $5.2 \pm 1.9 \mathrm{~B}$ & $6.0 \pm 1.7 \mathrm{~A}$ & $6.0 \pm 1.9 \mathrm{~A}$ & $2.7 \pm 1.0 \mathrm{~A}$ \\
\hline
\end{tabular}

Different letters within the same column indicate significant differences (Tukey-Kramer mean pair comparison, $\mathrm{P}<0.05$ ).

Data expressed as mean value \pm standard deviation. Attributes were scored using a 9-point hedonic scale 1=Dislike Extremely, 2=Dislike Very Much, 3=Dislike Moderately, 4=Dislike Slightly, 5=Neither Like or Dislike, 6=Like Slightly, 7=Like Moderately, 8=Like Very Much, 9=Like Extremely. The samples were ranked 1-4, 1 being most liked 4 being least liked. 


\section{Appendices}




\title{
APPENDIX A: Consent Form
}

\author{
West VirginiaUniversity \\ Davis College of Agriculture, Forestry and Consumer Sciences \\ Informed Consent for Participants in Research Projects Involving Human Subjects \\ Title of Project Sensory Evaluation of Nutritionally Enhanced Egg Product \\ Investigators Kristen Matak, Assistant Professor \\ Division of Animal and Nutritional Sciences \\ Helenia Sedoski, Graduate Student \\ Human Nutrition and Foods
}

\section{Purpose of this Research/Project}

The purpose of this research is to determine if there is a taste difference between nutritionally enhanced egg product verses whole egg.

\section{Procedures}

There will be 1 session that lasts about 30 minutes at each session. You will twice be presented with 6 samples and asked to rank certain sensory characteristics of the samples. As a panelist, it is critical for you complete your session.

The research will be conducted in the test kitchen at room 110 Agricultural Sciences Annex.

\section{Benefits/Risks}

Your participation in the project will provide information about sensory properties of nutritionally enhanced egg product. You will have access to the results of the panel at the completion of the study.

There are no identifiable risks associated with tasting these egg samples.

\section{Extent of Anonymity and Confidentiality}

The results of your performance are strictly confidential. Individual panelists will not be referred to in any publications or reviews.

\section{Compensation}

There is no monetary compensation for participation in this project. However, a candy treat will be offered at the end of the session. 


\section{Freedom to Withdraw}

If after becoming familiar with the sensory project you chose not to participate, you may withdraw without penalty. It is essential to the success of the sensory panel that you complete each session; however, there may be circumstances under which that you may chose not to complete your session, you may also withdraw at any time without penalty.

\section{Approval of Research}

This research has been approved by the Institutional Review Board for projects involving human subjects at West Virginia University. The IRB Approval is on file.

Should you have any pertinent questions about this research or its conduct, and research subjects' rights, and whom to contact in the event of a research-related injury to the subject, you may contact:

Kristen Matak (Investigator)

Helenia Sedoski (Investigator)

Paul Lewis (Director ANS)

Charles Craig (Director IRB)
Phone: (304) 293-2631 x 4401

Phone: (302) 293-2231 x 4413

Phone: (304) 293-6094 
APPENDIX B: Prescreening Questionnaire

\section{Pre-evaluation Questionnaire}

Instructions: For each question shade the circle beside the option that best fits your

Judge

answer.

1. Age

2. Gender

3. How often do you prepare your own food?

○ Daily

○ Weekly

○ Monthly

○ Never

4. How frequently do you consume eggs?

- Daily

○ Weekly

○ Bi-weekly

○ Monthly

○ Rarely

5. Which of the following do you prefer?

○ Whole egg

○ Egg White

$\circ$ Egg substitute

6. How important is monitoring your dietary cholesterol intake?

- Very important

- Slightly important

- Not important

7. How likely are you to buy a product containing omega-3 fatty acids, known to have heart health benefits?

○ Very likely

- Possibly

○ Not likely

8. How important is protein intake to you?

○ Very important

- Slightly important

- Not important

9. How likely are you to buy a ready-to-eat, cholesterol-free, omega-3 rich egg product in a stick form (YUM-EGG-A)?

○ Very likely

- Possibly

- Not likely 


\section{APPENDIX C: Hedonic Scale}

Instructions: You will receive a total of 4 egg samples. For each sample, please indicate your opinion about the characteristics being tested (color, odor, flavor, texture, mouth feel and overall liking) by highlighting the numbered box that best describes that attribute. Feel free to include comments to describe any noticeable attributes.

1=Dislike Extremely, 2=Dislike Very Much, 3=Dislike Moderately, 4=Dislike Slightly, 5=Neither Like or Dislike, 6=Like Slightly, 7=Like Moderately, 8=Like Very Much, 9=Like Extremely

Sample \#

Color

\begin{tabular}{|c|c|c|c|c|c|c|c|c|}
\hline \multicolumn{9}{|c|}{ Color } \\
\hline 1 & 2 & 3 & 4 & 5 & 6 & 7 & 8 & 9 \\
\hline \multicolumn{9}{|c|}{ Odor } \\
\hline 1 & 2 & 3 & 4 & 5 & 6 & 7 & 8 & 9 \\
\hline
\end{tabular}

Flavor
\begin{tabular}{|c|c|c|c|c|c|c|c|c|}
\hline 1 & 2 & 3 & 4 & 5 & 6 & 7 & 8 & 9 \\
\hline
\end{tabular}

Texture between fingers

\begin{tabular}{|l|l|l|l|l|l|l|l|l|}
\hline 1 & 2 & 3 & 4 & 5 & 6 & 7 & 8 & 9 \\
\hline
\end{tabular}

Mouth feel
\begin{tabular}{|c|c|c|c|c|c|c|c|c|}
\hline 1 & 2 & 3 & 4 & 5 & 6 & 7 & 8 & 9 \\
\hline
\end{tabular}

Overall liking
\begin{tabular}{|c|c|c|c|c|c|c|c|c|}
\hline 1 & 2 & 3 & 4 & 5 & 6 & 7 & 8 & 9 \\
\hline
\end{tabular}

Comments:

Sample \#

Color

\begin{tabular}{|l|l|l|l|l|l|l|l|l|}
\hline 1 & 2 & 3 & 4 & 5 & 6 & 7 & 8 & 9 \\
\hline
\end{tabular}

Odor
\begin{tabular}{|c|c|c|c|c|c|c|c|c|}
\hline 1 & 2 & 3 & 4 & 5 & 6 & 7 & 8 & 9 \\
\hline
\end{tabular}

Flavor
\begin{tabular}{|c|c|c|c|c|c|c|c|c|}
\hline 1 & 2 & 3 & 4 & 5 & 6 & 7 & 8 & 9 \\
\hline
\end{tabular}

Texture between fingers

\begin{tabular}{|c|c|c|c|c|c|c|c|c|}
\hline 1 & 2 & 3 & 4 & 5 & 6 & 7 & 8 & 9 \\
\hline \multicolumn{9}{|c|}{ Mouth feel } \\
\hline 1 & 2 & 3 & 4 & 5 & 6 & 7 & 8 & 9 \\
\hline \multicolumn{9}{|c|}{ Overall liking } \\
\hline 1 & 2 & 3 & 4 & 5 & 6 & 7 & 8 & 9 \\
\hline
\end{tabular}

Comments: -

\section{Comments on Attributes}

Color

Odor

Flavor

Texture

Mouth feel

\section{Comments on Attributes}

Color

Odor

Flavor

Texture

Mouth feel 


\section{APPENDIX D: Ranking Form \\ Ranking Form}

Judge

Instructions: Please assign each sample a number $(1-4)$. Use 1 for the sample you liked most and 4 for the sample you liked least. Use each number only once.

Sample:

Rank:

Sample:

Rank:

Sample:

Rank:

Sample:

Rank:

\section{Ranking Form}

Judge

Instructions: Please assign each sample a number $(1-4)$. Use 1 for the sample you liked most and 4 for the sample you liked least. Use each number only once.

Sample: Rank:

Sample:

Rank:

Sample:

Rank:

Sample:

Rank:

\section{Ranking Form}

\section{Judge}

Instructions: Please assign each sample a number $(1-4)$. Use 1 for the sample you liked most and 4 for the sample you liked least. Use each number only once.

Sample: Rank:

Sample: Rank:

Sample: Rank:

Sample: Rank: 